Furat Üniversitesi Sosyal Bilimler Dergisi

Firat University Journal of Social Science

Cilt: 26, Sayı: 1, Sayfa: 1-20, ELAZIĞ-2016

\title{
BÜYÜKÇAY HAVZASINDAKİ (ELAZIĞ) KIRSAL YERLEŞMELERİN COĞRAFİ ANALIZİ
}

Geographical Analysis of Rural Settlements in Buyukcay Basin

F. Ahmet CANPOLAT ${ }^{1}$

Selçuk HAYL $\dot{\mathbf{I}}^{2}$

\section{ÖZET}

Yerleşmelerin doğası itibariyle bir canlı gibi olması onun, zamansal ve mekânsal değiş̧ikliklere tepki verdiği, başkalaştığı anlamına gelmektedir. Kırsal yerleşmeler günümüzde sosyal ve iktisadi yapının değişmesinin yanında, kentlerin ve kentlileşmenin etkisiyle başkalaşmaya uğramaktadır. Bu başkalaşma meskenler, yerleşmeler ve arazi kullanım özellikleri gibi çeşitli coğrafi unsurlar üzerinden belirgin olarak gözlemlenmektedir.

Araştırma sahası, Elazığ ili sınırları içinde, Elazığ-Malatya Karayolu üzerinde yer alan ve coğrafi açıdan bir geçiş sahası-eşik özelliği gösteren, Büyükçay Havzasıdır.

Sahada yerleşmeler, tipolojik olarak mezra ve mahalle, morfolojik açıdan yol boyu, küme ve şekilsiz olarak sınıflandırılabilir. Havzadaki meskenlerin konumları üzerinde, ulaşım, eğim ve yükselti özellikleri etkili olmuştur. Küçük bir saha olmasına rağmen, arazi kullanım özellikleri bakımından çeşitlilik göstermektedir. Nüfus itibariyle azalma trendinde bir coğrafi ünitedir.

Araştırmanın amacı: yüzölçüm itibariyle küçük bir saha olmasına rağmen, 115 kadar iskan biriminin yer aldığı, yerleşme özellikleri bakımından kendi içinde farklılıklar arz eden ve zamansal süreç bakımından da değişim gösteren, sahadaki bu yapının, coğrafi analizini yapmaktır.

Anahtar Kelimeler: Elazığ, Kırsal Coğrafya, Büyükçay Havzası, Kırsal Yerleşme, Kırsal Mesken

\section{ABSTRACT}

The settlement of such a nature as to be alive to be responsive to its temporal and spatial changes, which means that they metamorphose. Rural settlements today next to the social and economic structure changes are subject to alteration under the influence of cities and urbanized. This alteration of dwellings, settlements and observed significantly over various geographical factors, such as land use characteristics.

Büyükçay Basin where the research area is located in the province of Elazı̆g, on the Elazig-Malatya highway. The basin indicates geographically a transition zone (threshold) the property.

Settlements in the area can be classified, typological as mezra (settlement unit smaller from village) and mahalle (settlement unit smaller from village), morphologically linear, clusters and amorphous. On the location of the houses in the basin has been effective transportation, slope and elevation properties. Although a small area shows variety in terms of land use characteristics. The population of the basin tends to decrease.

The basin, although is a small area is located in around 110 housing units. Area, in terms of settlement characteristics, varies also vary in terms of their temporal process. The aim of the research is to analyze geographically to the basin.

Keywords: Elazığ, Rural Geography, Buyukcay Basin, Rural Settlement, Rural House

\section{GíRiş}

Büyükçay havzası, ülkemizin Doğu Anadolu Bölgesi'nin Yukarı Fırat Bölümü’nde Elazığ ilinin güneybatı kesiminde, Güneydoğu Toroslar dağ kuşağının kuzey kenarında genel olarak doğu-batı doğrultulu uzanan dağlar (Karga Dağı ve Bulutlu Dağı) arasında yer almaktadır (Harita 1).

Büyükçay havzası 272,7 km² alana sahiptir. Havzada 19 köy ve bu köylere bağl1 61 mezra ile 35 mahalle olmak üzere toplam 115 yerleşme bulunmaktadır. 2015 yılı itibariyle 1543'ü kadın,

\footnotetext{
${ }^{1}$ Arş. Gör., Firat Üniversitesi Coğrafya Bölümü, facanpolat@firat.edu.tr

${ }^{2}$ Yrd. Doç., Dr. Fırat Üniversitesi Coğrafya Bölümü, shayli@firat.edu.tr
} 


\section{F.Ü. Sosyal Bilimler Dergisi 2016-26/1}

1446's1 erkek olmak üzere toplam nüfusu 2989'dur. İnceleme sahası mevsimlik göçe bağlı nüfus hareketliliğine sahne olmaktadır.

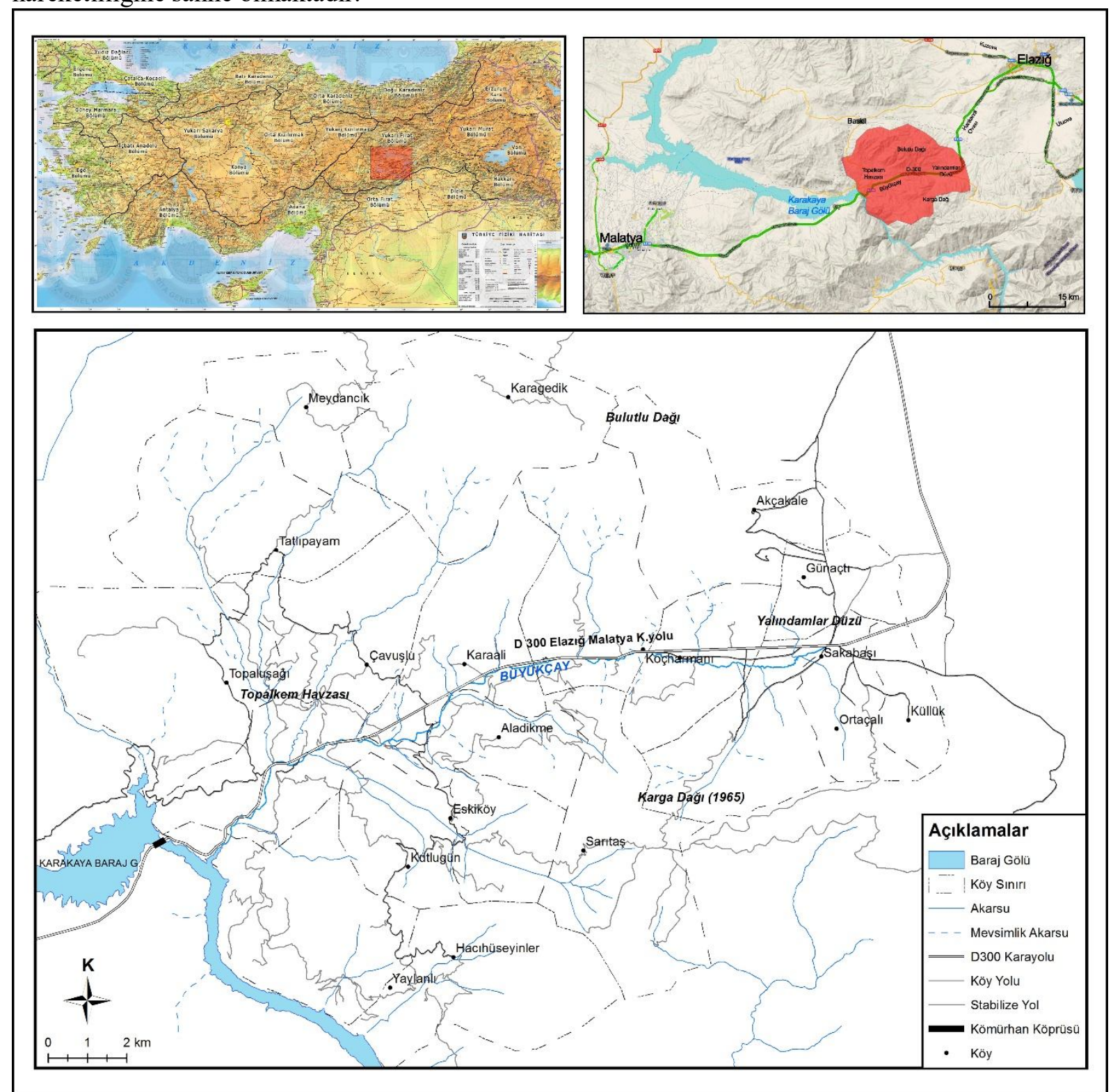

Harita 1: Büyükçay Havzasının (Elazı̆g) Lokasyon Haritas1

Doğu Anadolu bölgesinde yapılan araştırmalar, insana ait ilk izlerin Üst Paleolitik dönem'den itibaren görülmeye başlandığına işaret etse de, yerleşik yaşam ve kültürel süreç bu zorlu coğrafyada Neolitik Dönem sonunda başlar. Neolitik dönemin izleri daha çok güneyde, daha olumlu coğrafi ve iklimsel koşullara sahip olan Malatya-Elazığ bölgesinde gözlenir. Bu yöre aynı zamanda Büyük Mezopotamya dünyası ile yoğun ilişkileri olan oldukça özel bir alandır (Işsklı, 2014:2). Mezopotamya'dan kuzey yönlü ve daha çok Frrat ve/veya Dicle nehirlerinin vadilerini izleyerek Anadolu'ya yayılan iskan üniteleri Anadolu'da da doğal yolları izlemişlerdir (Akdemir, 1996:47). Büyükçay Havzası da Elazığ-Malatya arasında bir geçiş sahası olmasının yanında böyle bir tabii yol konumunda bulunması ve su kaynaklarının mevcudiyetine bağlı olarak, neolitikten itibaren yerleşim sahası haline gelmiş olması muhtemel gözükmektedir. Yakınındaki Erken Tunç çağı ve Demir çağı olarak tarihlendirilen Habibuşağ 1 , Demir çağı olarak tarihlendirilen Dilektepe ile Pıncirik höyükleri (Kalkolitik ve Erken Tunç Çăğ1) bu durumu desteklemektedir. 
Araştırma sahasının genel olarak yer şekillerine baktığımızda Büyükçay ve kollarının açmış olduğu vadilerle parçalanmış eğim ve engebeliliğin oldukça fazla olduğu bir yapı görülmektedir. Havza içerisindeki önemli düzlük sahalar, doğuda Ortaçalı köyü ile Yalındamlar köyü arasındaki düzlük saha ile batıda Topaluşağı köyünden, Çavuşlu köyüne kadarki plato tarzında akarsular tarafindan parçalanmış düzlük sahanın bulunduğu kesimdir (Harita 1). Havzadaki en yüksek noktayı, Heybeli Dağ üzerinde yer alan Karataş Tepesi $(2031 \mathrm{~m})$ en alçak yeri ise $680 \mathrm{~m}$ ile Fırat nehri oluşturmaktadır. Havza içindeki yükselti farkı 1351 m.dir.

Kırsal yerleşmeler beş temel özelliğine göre analiz edilmektedir. Bunlar; yerleşmenin tipi, şekli, dokusu, süresi ve tarzıdır. Bu çalışmada da bu beş temel özelliğe göre sahadaki yerleşmeler analiz edilmektedir.

\section{METODOLOJİ}

Araştırma, coğrafi unsurların kırsal yerleşmeler üzerindeki olumlu ve olumsuz etkilerini belirlemeye odaklanmaktadır. Araştırmanın sorusu, yerleşme fizyonomisi ve tipolojisinin ortaya çıkmasında etkili olan coğrafi olguların neler olduğudur. Çalışmada havzada yer alan 122 yerleşim yerinin tamamı araştırmaya dahil edilerek, yerleşmelere etki eden değişkenler üzerinden değerlendirilmektedir. $\mathrm{Bu}$ değerlendirmeler CBS ortamında veri üreterek veya verileri ekleyerek mekânsal istatistik ve analizler aracılığıyla yapılmaktadır.

Çalışmanın birincil veri kaynaklarını arazi gözlemleri ve mülakatları ikincil veri kaynaklarını ise nüfus istatistikleri, ilgili literatür ve mekânsal veriler oluşturmaktadır. Çalışmada kullanılan mekânsal verileri yerleşme ve meskenlerin konumları, sayısal yükselti modeli ve uydu görüntüleri oluşturmaktadır.

Araştırma da ilk olarak havzadaki nüfusun gelişimini (1935-2013) incelemektedir. Daha sonra yerleşme tiplerini, ortaya çıkma süreçlerini, değişimini ve özelliklerini ele almaktadır. Üçüncü olarak Yerleşmelerin şekli, dokusu, idari yapısı ve toponimik özellikleri değerlendirilmektedir. Son olarak Jeomorfolojik özelliklerin yerleşmelerin kuruluş yerine ve arazi kullanımına etkileri incelenmektedir.

\section{NÜFUSUN GELIŞ̧iMI}

Fiziki ve beşeri özellikleri itibariyle küçük bir coğrafi ünite olan Büyükçay havzasının tarihi dönemlerdeki durumu net olarak bilinmemekle beraber geçiş güzergâhı üzerinde olması dolayısıyla tamamı olmasa da belli bir bölümünün geçmişten günümüze kadar kullanıldığı söylenebilir. Bu nedenle sahadaki köylerden, Akçakale, Ortaçalı (Sefernik), Sakabaşı (Pincirik), Yalındamlar (Güdeyik) ve Tatlıpayam (Sersük) köyleri hariç, 16.yy sonrasında kurulmuş olduğu söylenebilir.

Osmanlı öncesi döneme ait verilerin mevcut olmaması nedeniyle buradaki yerleşmelerle ilgili, Osmanlı hakimiyetine girdiği 1516 yılından günümüze kadarki 500 yıllık süreç hakkında birtakım bilgiler mevcuttur. Saha Harput sancağına bağlı Hersini nahiyesi dahilinde yer almaktadır. Sahadaki yerleşmelerin kökeni Parçikan, Aluçlu ve Herdi aşiretlerine dayanmaktadır (Çakar, 2012). Havzada, 1518 'de yalnızca Yalındamlar köyünde 2 hane (14 kişi) görülmektedir. 1523'te 258 kişi bulunmaktadır. 1566 yılında ise toplamda yaklaşık 1413 kişi bulunmaktadır.

Nüfusun tarihsel süreç içerisindeki seyrine bakıldığında genel olarak üç dönemde ele alıp incelemek mümkündür. Bu üç dönemden ilki 1935-1945 arasıdır. Bu zaman dilimini nüfusta belirgin bir artış olmadığından durağan devre olarak nitelendirilebilir. İkinci dönem olarak 1945-1980 arasında, nüfusun artış eğilimine bağlı olarak dinamik dönem ve son olarak 1980-2015 yılları arasında nüfusun tekrar 1935 yılındaki nüfusuna döndüğ̈ ve tekrar durağanlaştığ bir dönem olarak ele alınabilir. 2011 sonrasındaki artış yerel seçimlere bağlı ikamet değişikliğinden kaynaklanan bir artıştır. 


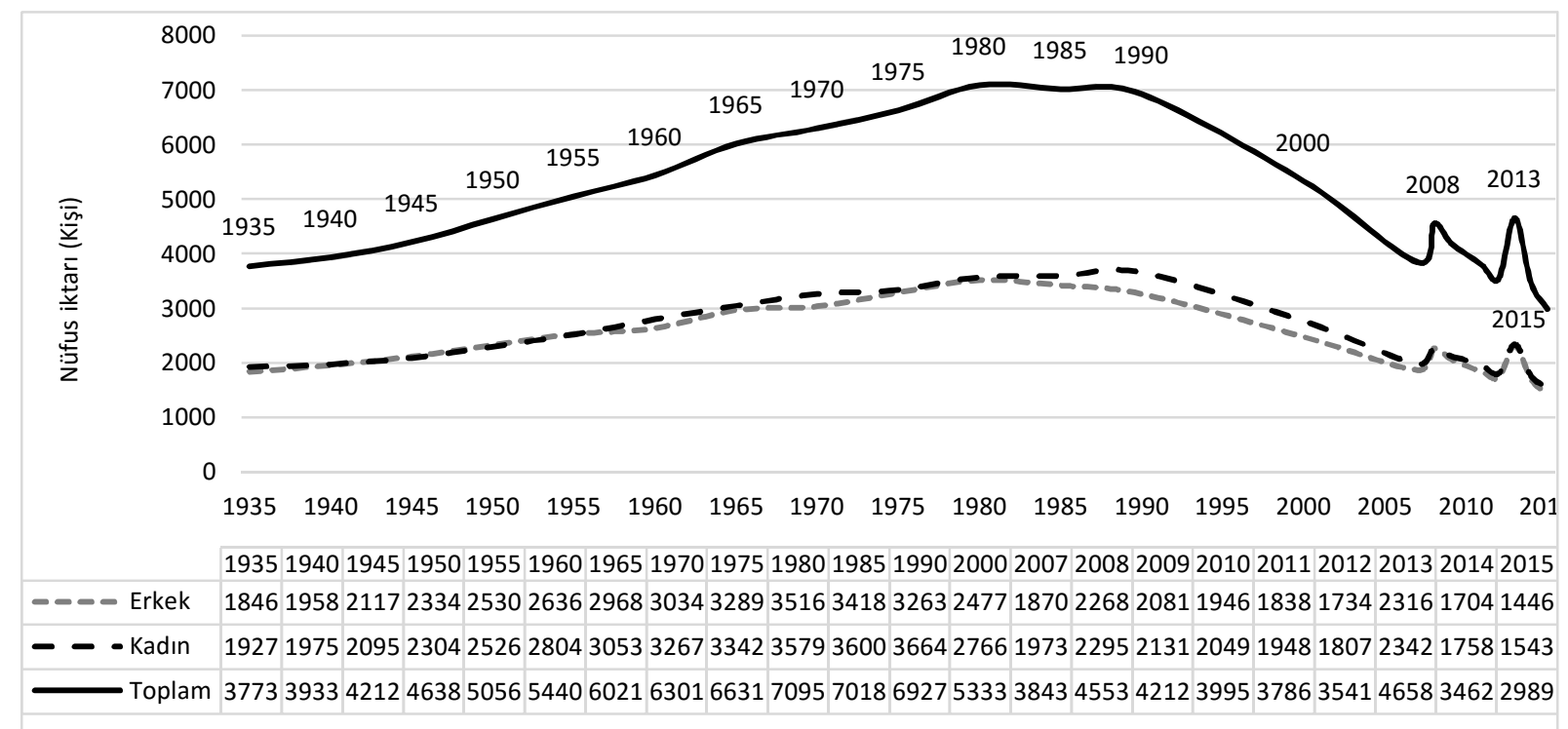

Grafik 1: Büyükçay Havzasının Nüfus Gelişimi (1935-2013) (DİE, G.N.S. [1935-2000], TÜİK, ADNKS [2007-2013] )

\section{YERLEŞME TÍPOLOJISİ}

Havzanın doğusundaki kır-altı iskan birimlerinde mahalle sistemi batısında ise mezra sistemi görülmektedir. Bu ayrım yerleşmenin köy idari merkezi ile arasında topografik bir engel olup olmamasına göre yapılmıştır. Sonuçta havzadaki tüm köyler çok yerleşmelidirler. Küçük bir havza olmasına rağmen araştırma sahasında yerleşme sayısının bu kadar fazla olması sahanın yerleşme tarihi ve coğrafi ortam koşulları ile ilgilidir.

17. yy sonlarından itibaren Osmanlı sosyal ve askeri yapısının bozulması sonucunda çeşitli bölgelerde Celali isyanları çıkmış ve yerleşik halkın sıkıntısı artmıştır. Bu dönemde Osmanlı yöneticileri asayişi sağlamak ve toprak gelirlerinin tekrar artmasını sağlamak amacıyla iskan siyaseti izlemiş̧ir. Devletin sağladığı olanaklarla konar-göçer aşiretlerden bazıları kendiliklerinden yerleşik hayata geçmek istemişler ve çadır kurarak ya da konakladıkları geçici mekanlarda ev yaparak yerleşmişlerdir. Yerleşen nüfus arttıkça bu göçebe yerleri yeni köy ve kasabalara dönüşmüştür (Babuş; 2006, Sf. 32, 33). Bu süreç havza için de geçerli bir durumdur.

Araştırma sahasının doğusunda gelişen mahalle sisteminin, ortaya çıkmasında etkili faktörler;

- Birikinti konilerinin verimli arazi özelliği ve bunun sonucunda belirginleşen tarla tarımı,

- Sahada eğim değerlerinin az olması,

- Şehre ve ana karayoluna yakın olmasıdır.

$\mathrm{Bu}$ sebeplere bağlı olarak bu kesimde yerleşme, gevşek dokulu hale gelmiştir. İnsanlar kendi arazisi üzerinde meskenlerini inşa etmişlerdir. Zamanla bu meskenlerin yanına yenileri eklenmiş ve sahada öbekler halinde yerleşmeler ortaya çıkmıştır. Her bir iskan grubu mahalle olarak belirgin hale gelmiştir.

Araştırma sahasının bu kesimindeki yerleşmelerin tarihsel değişim süreci ile ilgili olarak şu aşamalar belirtilebilir;

I. Devre (18 yy. öncesi); Pirhasan-Bulutlu ve Karga Dağları çevresindeki su kaynaklarında köyler kurulmuştur. $\mathrm{Bu}$ aşamada köylerde ağırlıklı olarak hayvancılık yapılmaktadır. $\mathrm{Bu}$ aşama köylerin kuruluşu ile ilgili verilen daha önceki verilerden hareketle 16-17. yy. içerisinde gerçekleştiği düşünülmektedir. Bu aşamadan önce buralar geçici olarak kullanılan sahalardandır. Tıpkı Anadolu'nun geri kalanında olduğu gibi nomadik kültür yaşayan insanların geçici olarak konakladıkları yerler arasindaydı.

II. Devre(18 yy. sonrast); Bu aşamada bitkisel üretim ve hayvancılığı birlikte yapabilmek için yerleşmeler vadiler ve çevresindeki uygun yerlere taşınmıştır. Bu taşınma ve sedanter kültüre geçişin, 
Osmanlı Devletinin son dönemlerine doğru vergiyi daha rahat toplamak adına, 18. yy.'in sonlarına doğru gerçekleştiğini söyleyebiliriz (Babuş, 2006: 32,33).

III. Devre (1980 sonrası); Son aşamada ise köyler, bitkisel üretimin ağırlıkta olmasına bağlı olarak birikinti konileri üzerindeki verimli arazilerin hemen yanı başında kurulmuştur. Bu köylerde ulaşım özellikleri ve şehre yakınlığa bağlı olarak, yeni meskenlerin, tarlaların yakınında kurulması ve bunlara yenilerinin eklenmesiyle oluşan, yeni mahalleler, gevşek dokuya sahip yerleşme özelliğinin ortaya çıkmasına neden olmuştur. Mahalle sisteminin ortaya çıkması ve gelişmesi belirgin olarak 1980'den sonra gerçekleşmiştir. Bu değişim üzerinde ormanların koruma altına alınmasıyla, keçilerin buralara sokulmasının engellenmesi, küçükbaş hayvancılıktan büyükbaş hayvancılığa geçişe neden olmuş, ayrıca tarla tarımının da daha fazla önem kazanmasına neden olmuştur.

Havzada Karaali boğazından sonraki batı kesiminde ise yerleşmelerde mezra sistemi görülmektedir. Batıdaki bu mezra sisteminin ortaya çıkmasında etkili faktörler şunlardır;

- Drenaj ağı ve su kaynakları,

- Eğim değerlerinin fazla olmas1,

- Arizali topografya,

- Yükselti.

Karga Dağının batısından Kömürhan Boğazına kadarki köylerde (Karaali köyü ve Topaluşağı köyü hariç) yerleşmeler drenaj ağının kontrolündedir. Buradaki yerleşmelerin neredeyse tümü mezradır. Ancak bazıları idari açıdan köydür.

$\mathrm{Bu}$ kesimde yukarıda sayılan faktörler yerleşmeleri ortaya çıkaran veya sınırlandıran faktörlerdir. Drenaj sisteminin ve eğimin izin verdiği küçük parçalarda yerleşmeler vardır. Bu yüzden yerleşmelerde saçılma vardır. Ancak bu saçılma mesken bazında değil, yerleşmeler bazındadır. Yani meskenler toplu halde olmasına rağmen buradaki çok sayıda yerleşme, farklı konumlarda yer almaktadırlar. Drenaj ağı sadece yerleşmenin kurulacağı yeri değil, aynı zamanda bitkisel üretimin ve hayvancılık yapılacak alanları belirlediğinden, uygun sahalarda yerleşmeler ortaya çıkmıştır.

Vadiler ve yamaçlardaki su kaynaklarının varlığı yerleşmelerin burada kurulmasında bir diğer önemli faktördür. Hem içme ve kullanma suyu, hem de arazilerin sulanması için su kaynaklarının fazlalığ 1 yerleşme yerinin seçiminde etkili olmaktadır. Nüfusun burada artması veya azalmasında dolayısıyla yerleşmelerin büyümesinde veya küçülmesinde de bu durum etkilidir. Örneğin günümüzde Sakabaşı, Çavuşlu ve Karaali köylerinde nüfusun fazla olmasının sebepleri arasında, su kaynaklarının varlığına bağlı üretim çeşitliliği ve fazlalığı belirleyici olmaktadır.

Araştırma sahasının bu bölümündeki mezra sisteminin ilk istisnası olan Karaali köyünde, sadece mezra sistemi değil, doğudakine benzer mahalleler de ortaya çıkmıştır. Bu durum üzerinde tıpkı Yalındamlar düzünde olduğu gibi birikinti konilerinin varlığı ve D-300 karayoluna çok yakın olunmasına bağlı olarak bu köyde, yola yakın yeni meskenlerin yapılması ve bunlara başkalarının eklenmesi etkili olmuştur.

Topalkem havzasında ise durum biraz daha farklıdır. Aşınım düzlükleri çevresinde geçmişte var olan mezra sistemi, kayısı yetiştiriciliği nedeniyle adeta mahalle sistemine geçmiş ve mezraların yanında yeni mahalleler gelişmiştir. Bu duruma geniş aşınım düzlükleri zemin hazırlamıştır. $\mathrm{Bu}$ yönüyle doğudaki bölüme benzemektedir. Buradaki mezra sisteminin yanında yeni mahalleler ortaya çıkmaktadır. Topalkem havzası, Yalındamlar düzünün ilk halleri gibi düşünülebilir. Zamanla yeni mahallelerin ortaya çıkmasıyla gevşek doku çok daha belirgin hale gelebileceği düşünülmektedir.

Havzanın engebeli yapısına bağlı olarak yerleşim yeri olarak kullanılamayacak alanlar arasında Karga Dağı, Heybeli Dağ ve Pirhasan Dağlarının aşırı eğimli ve aşınmış kesimleri ile Büyükçay’a bağlı dere ve çayların oluşturduğu derin kertik vadiler ve kanyon biçimli vadilerin bulunduğu sahalar ile devlet tarafından ağaçlandırılan arazilerin bulunduğu sahalardır. Araştırma sahasında bitki örtüsü, yerleşmelerin dağılışında doğrudan bir etkiye sahip değildir. Ancak bu arazilerin devlet tarafindan koruma altına alınması ve yerleşime kapalı olması, yerleşmeyi sınırlandıran bir faktör olmaktadır. 


\section{F.Ü. Sosyal Bilimler Dergisi 2016-26/1}

Araştırma sahasında Topalkem Havzası ve Yalındamlar Düzü olmak üzere, iki önemli düzlük saha vardır. Bu iki önemli düzlük sahada yerleşmeler daha fazladır. Bu duruma Yalındamlar düzü üzerindeki verimli alüvyal toprak örtüsünün varlığı ve Topalkem havzasındaki parçalı düzlükler üzerindeki kırmızı-kahverengi topraklar da katkı sağlamaktadır.

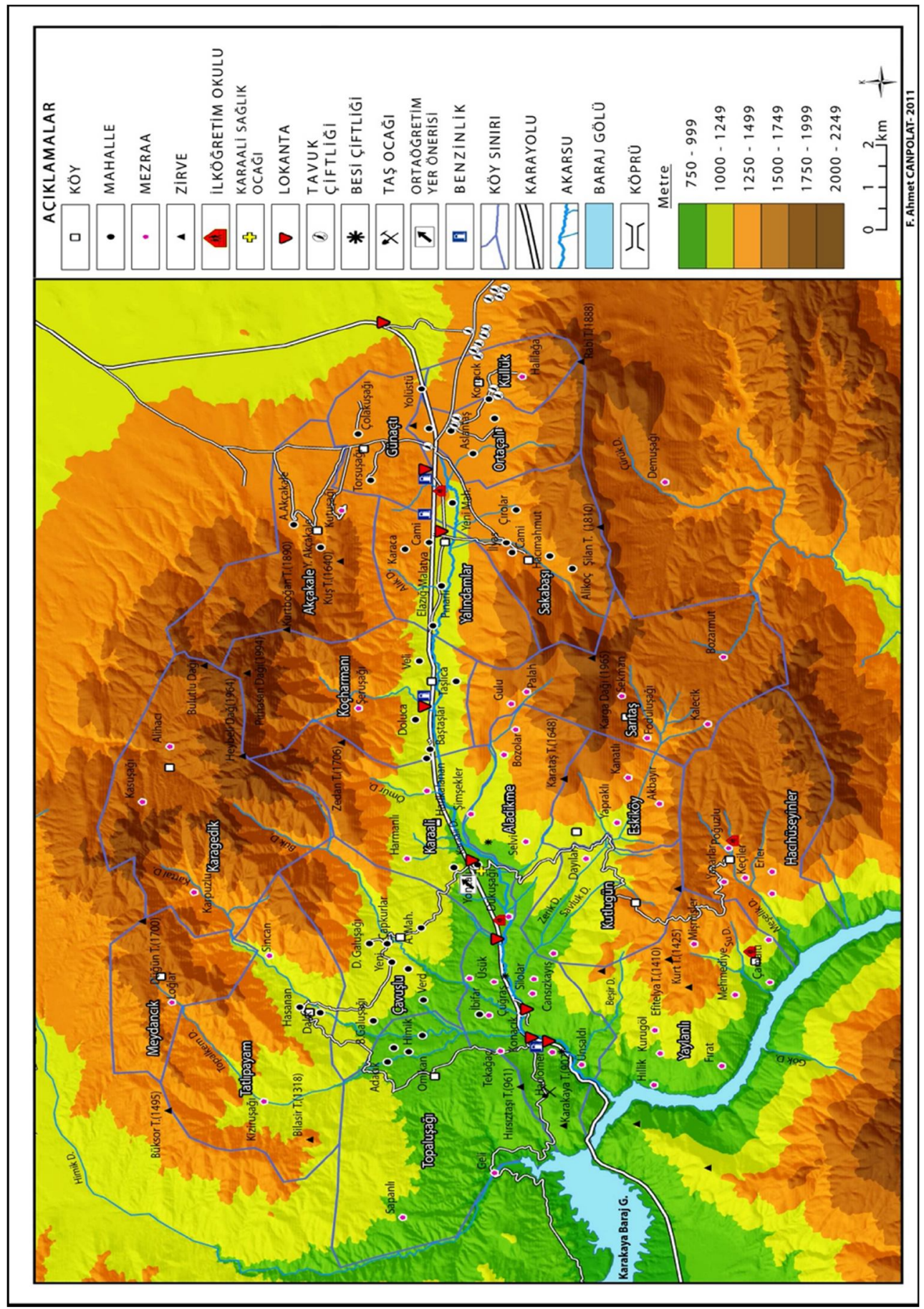

Harita 2: Büyükçay Havzasında (Elazığ) Yerleşmelerin Dağılımı (2011)

Yükselti; yerleşmelerin dağılışında etkili oaln doğal faktörler arasında yer almaktadır. Büyükçay havzası küçük bir alan olmasına rağmen, yer şekilleri itibariyle çeşitlilik gösteren bir alandır. Havza içerisinde yükselti farkı 1300 metreyi bulmaktadır. Dört önemli dağın ve bunları yaran vadilerin ve platoların varlığı kırsal yerleşmelerin dağılışında belirgin bir kademelenmenin ortaya çıkmasına neden olmuştur. 
Araştırma sahasında yerleşmenin üst sınırı 1700 metredir. Bu sınır, Elazı̆̆ il genelinde $1880 \mathrm{~m}$. Türkiye'de ise 2500 metredir. Araştırma sahasında doğal olarak yükselti arttıkça yerleşmelerin sayısında ve nüfus miktarında azalma söz konusu olmaktadır. Araştırma sahasında en yüksekte yer alan yerleşme Sarıtaş köyüne bağlı Sekman mezrasıdır (1700 metre, Nüfusu:25).

Havzadaki meskenlerin büyük çoğunluğu (\% 70,4’ ü) 700-1300 metre aralığında yer almaktadır. 900 metreye kadar olan alanın havzada fazla yer kaplamaması ve Firat nehri kıyısındaki fazla eğimli sahalara karşı1ık gelmesinden dolayı mesken sayısı azdır. 1100-1300 bandında yer alan meskenler Yalındamlar Düzü ve yakınında yoğunlaşmaktadır ve bu bantta mesken yoğunluğu en fazladır. Bu durum üzerinde D-300 karayolu çevresinde yerleşmeye müsait topografik koşullardan kaynaklanmaktadır. Havzada önemli morfolojik üniteler olan Bulutlu Dağı, Pirhasan Dağı, Heybeli Dağı ve Karga Dă̆ı, yerleşmelerin yükselti değerlerinin fazla olmasının temel sebebidir. 1501-1700 metre aralığında meskenlerin yalnızca \%4,3'ünün (64) yer alması, ulaşım güçlüğü, eğim değerlerinin oldukça artması ve havzanın verimsiz arazilerinin bulunduğu alanlara karşılık gelmesinden kaynaklanmaktadır (Harita 3).

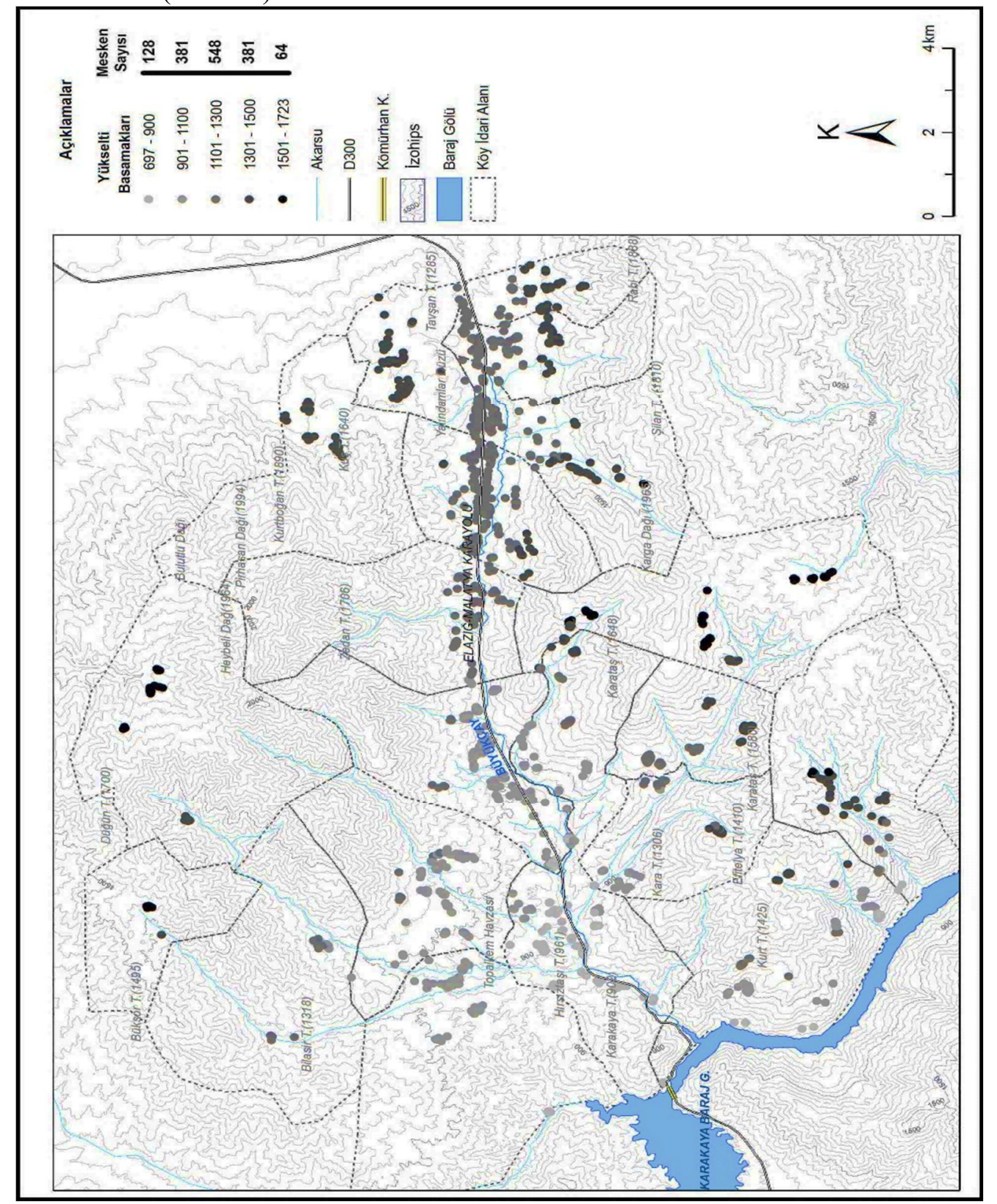

Harita 3: Büyükçay Havzasında (Elazığ) Meskenlerin, Yükselti Basamaklarına Göre Dağılışı (2014) 


\section{F.Ü. Sosyal Bilimler Dergisi 2016-26/1}

Meskenlerin konumu üzerinde etkili olan bir diğer topografik unsur eğimdir. Meskenlerin \%59'u (885) \%0-20 eğim değerlerine sahip yerlerde konumlanmışlardır. Bu eğim aralığındaki alanlar Yalındamlar düzü ile Topalkem havzasına karşılık gelmektedir. \%21-30 bandındaki meskenler tüm meskenlerin \%22'sini (328) oluşturmaktadır. Bu meskenler, Karaali boğazı çevresinde ve drenaj ağına bağlı yerleşmeye uygun alanlarda yoğunlaşmaktadır. \%31 ve üzeri eğim değerlerindeki meskenler toplam meskenlerin \%19.2'sine (289) karş1lık gelmektedir ve bu meskenler havzanın kuzey ve güneyindeki dağlık kütleler üzerindeki yerleşmelerde konumlanmaktadırlar (Harita 4).

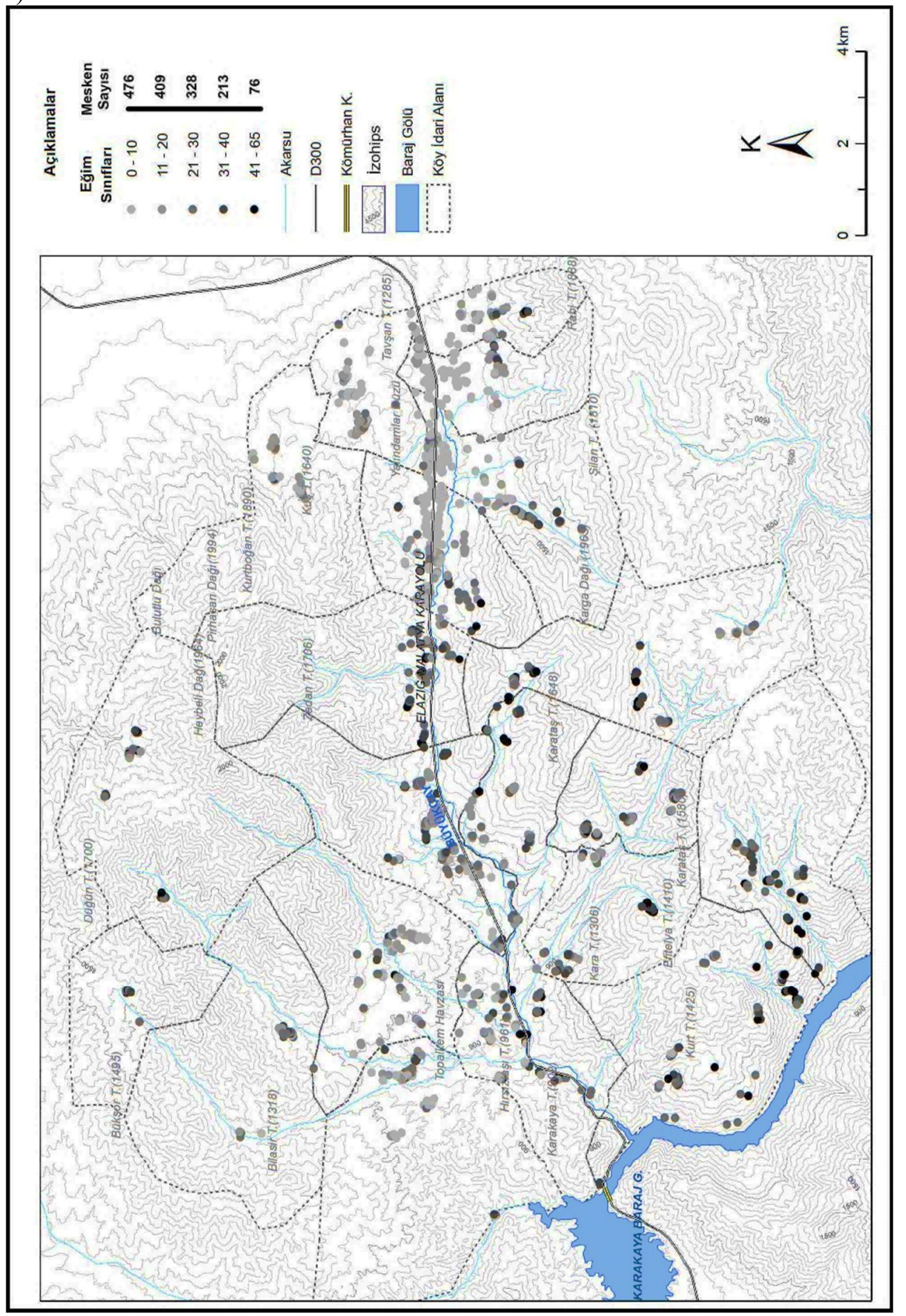

Harita 4: Büyükçay Havzasında (Elazığ) Meskenlerin Eğim Sınıflarına Göre Dağılışı (2014) 
Büyükçay havzasında yerleşim yerlerinin farklılaşması üzerinde en etkili beşeri faktör, ulaşımdır. Bu durum 1980 yılı ve 2010 yılında Elazı ğ-Malatya karayolunun geçtiği güzergâhta meskenlerin yoğunlaştığı alanlar, karşılaştırıldığında belirgin olarak tespit edilebilmektedir. Köylüler, farklı konumlarda bulunan tarlalarından, yola yakın parsel üzerindekini tercih ederek evini yapmaktadır. Ayrıca köylerde satışa çıkarılan arazilerden, en çok rağbet görenler de karayoluna yakın olanlar olması süreci hızlandırmaktadır. Bu duruma belirgin bir örnek olarak, Koçharmanı köyü gösterebilir. Bu köy daha önce karayolunun kuzeyinde iç kesimde yer alan bir köy iken, insanların yola yakın olma isteğine bağlı olarak zamanla meskenler yer değiştirmiş yenileri yapılmıştır. Sonuçta köyün tamamı yol kenarına taşınmıştır. Aynı olgu, sahanın doğusunda da yaşanmaktadır. Ortaçalı ve Küllük köylerinde 2005 yılındaki depremden sonra yıkılan evlerin yerine, devlet desteği ile kurulan yeni evler Gözeli yolu yakınına ya da D-300 karayolu yakınına yapılmıştır. Ayrıca Sakabaşı, Günaçtı ve özellikle Yalındamlar köyündeki yeni meskenler, D- 300'e yakın yerlerde yapılmıştır. Ulaşımın yerleşmeler üzerindeki bu etkisinin ortaya çıkmasında; temel ihtiyaç malzemelerinin temini, çocukların okula gitmesi, sağlık ihtiyaçları, ürünlerin kolay pazarlanması, günübirlik gidiş-geliş yapmada kolaylık gibi benzer birçok neden sayılabilir.

Araştırma sahasının şehre yakın olması, nüfus, yerleşme ve ekonomik özellikler üzerinde etkili olmaktadır. Zaten "ülkemizdeki büyük şehir merkezleri, yakın çevrelerinden başlayıp, şehir yerleşmesinin büyüklüğü ile orantılı olarak, memleketin uzak köşelerine kadar kır yerleşmelerini etkilemektedirler" (Tümertekin, 1973:4).

Sosyal sebepler içerisinde sayılan güvenlik faktörü yerleşme yerinin seçiminde bir diğer faktör olarak karşımıza çıkmaktadır.

16.yy'daki Celali isyanları ve o dönemdeki kırsal kesim üzerindeki baskılar yollardan nisbeten uzak, eğimli arazilerde üç beş hanelik küçük yerleşme birimlerini oluşturmuştur. Bunun sonucunda açık sahalarda verimli ovalarda yaşayan nüfusun dağılmasına neden olmuştur. 19. yüzyıla kadar süren iç kargaşa nedeniyle kır yerleşimleri daha çok dağ yamaçlarında toplanmaya başlamıştır. Bunun nedeni köylülerin birlik olup dış tehlikelere karşı savunma ihtiyaçlarıydı (Gözenç vd.1998:91). Bu durum araştırma sahasında da görülmektedir. Yaylanlı, Meydancık, Eskiköy, Sarıtaş, Kutlugün, Hacıhüseyinler ve Karagedik köyleri sapa, erişimi zor ve yükseltinin fazla olduğu alanlarda kurulmuş köylerdir. Örneğin Sarıtaş köyü Karga Dağının güney yamacında yüksek bir mevkide ve çok eğimli bir alanda; Yaylanlı ve Hacıhüseyinler ise erişimi zor, sapa ve yüksek eğimli bir yerde kurulmuştur. Bu durum köylerin ve bağlılarının ulaşımında hizmetlerin götürülmesinde ve diğer yerleşmelerle entegrasyonunda problemler ortaya çıkarmaktadır. Örneğin Yaylanlı köyünde karayolundaki problemler nedeniyle kış aylarında Karakaya barajı üzerinden, su yoluyla ulaşımın sağlandığı durumlar yaşanmaktadır. Karagedik ve Meydancık köylerinde derelerin köy yolu ile kesiştiği yerlerde zaman zaman oluşan sıvı zemin geçişi zorlaştırmaktadır.

Havzadaki bağ-bahçe evleri basit kulübe niteliğinden daha çok tek ev şeklinde karşımıza çıkmaktadır. Zaten sahadaki yaz-kış nüfus hareketliliği ve sahadaki birçok ailenin bahçe tarımı yaparak geçimini sağlaması sebebiyle burada daha çok bu tür evler tek ev şeklinde ve bir nevi yazlık ev şeklinde kullanılmaktadır. Araştırma alanında köy, mezra veya mahallelerden uzakta, tarım arazisinin hemen yanı başında yapılmış yaklaşık 154 mesken vardır. Bu meskenler bağ-bahçe evi tanımındaki gibi, hasat döneminde geçici olarak kullanılan meskenlerdir. Eğreti bir konut özelliğinden ziyade eklentileriyle birlikte ayrı bütün bir ev niteliği göstermektedir. Eğer bu evleri yerleşmelerden ayrık evler olarak düşünmezsek ve yerleşim birimlerinde tanımlardaki özellikleri bünyesinde barındıran evleri de bağ-bahçe evi olarak kabul edersek, araştırma sahasındaki evlerin yarıdan fazlasının bu nitelikte olduğunu söyleyebiliriz.

Araştırma sahasındaki bağ-bahçe evlerine daha çok havzanın iç ve batısında, kayısı yetiştiriciliğinin yoğun olarak yapıldığı kesimlerde rastlanılmaktadır. Özellikle Koçharmanı, Karaali, Aladikme ve Çavuşlu çevresinde yoğunlaşan bu evler havzanın kuzeyine ve doğusuna doğru azalmaktadır.

Araştırma sahasındaki mevcut D-300 karayolu Elazı̆̆’1 Malatya'ya bağlayan ana güzergâhtır. Aynı zamanda bu yol Bingöl, Tunceli, Diyarbakır ve daha doğudaki illerin batıdaki illerle 


\section{F.Ü. Sosyal Bilimler Dergisi 2016-26/1}

ulaşımlarının sağlandığı ana güzergâhtır. Dolayısıyla trafik yoğunluğu oldukça fazladır. Bu durum beraberinde benzin istasyonlarının sayısının artmasında teşvik edici bir unsurdur. Araştırma sahasında D-300 karayolunun yaklaşık 22 km'lik bölümü yer almaktadır. Bu karayolu üzerinde 4 benzinlik 8 lokanta bulunmaktadır (Harita 2). Buradaki benzinliklerin hemen yanı başında lokantalar bulunmaktadır. Ayrıca sadece lokanta hizmeti veren yerler de mevcuttur. Bu tesislerde çalışan insanlar genelde benzinlik sahibinin yakınları veya kendi köylüleridir. Dolayısıyla sahadaki ekonomiye hizmet veren ve sürekli olarak burada kalınan bu birimler yanlarında henüz mesken yapılmamış olmasına rağmen kır-altı iskân çekirdeği olarak değerlendirilebilir.

Araştırma sahasındaki 4 benzinliğin yakınında bulunan meskenlerde toplamda 40 civarında nüfus barınmaktadır.

\section{MEZRALAR}

Mezra, köylerin müşterek geçim sahasının dışında kalan ve o sahadan mutlaka bir relief ile ayrılmış daha başka bir geçim sahası olmak gibi bir özellik gösterir.

Mezra, Anadolu'nun doğu yarısının en tipik iskân tiplerinden biridir. Doğu Anadolu Bölgesi’ne has bir tipi olması ve bu tipin batı yarıda pek bulunmayışı, mezranın Doğu Anadolu'nun coğrafi özelikleri ile bir takım ilgileri bulunabileceğini ilham eder (Tunçdilek, 1967:45- 47).

Mezra terimi ekilen yer, ekilip biçilecek yer veya tarla, ekilmiş tarla gibi anlamları vardır (Alagöz, 1941:155). Bununla birlikte bu yerleşme tipleri, yerleşme çekirdeği (tek ev ve ev eklentileri) ve köy yerleşmesi arasında, bir geçiş tipi, veya ara tip yerleşme olarak da kabul edilir (Tanoğlu, 1966:253), aslında mezralar her zaman ziraat yapilan ve ya ekilen tarla anlamına gelmez. Ancak Doğu ve Güneydoğu Anadolu bölgelerindeki mezralar genel olarak hayvan yetiştirme ve ekip biçme faaliyetinin sürdüğü, geçici ve ya daimi yerleşmelerdir ekip biçme faaliyeti olarak daha çok Karadeniz bölgesinde kullanılan bir yerleşme tipidir. Doğu Karadeniz Bölümü’nde köylü ailelerin yaylalardan köye ve köyden yaylaya intikalinde; yılda iki kez konulup göçülen, kalındığı ilkbahar ve güz mevsimlerinde kullanıldığı görülür (Doğanay,1994:280).

Doğu Anadolu'daki iskan şekilleri ile onların büyüklük ve küçüklüğünü tayin eden faktör her şeyden evvel geçim sahasının hudutlarıdır (Tunçdilek, 1967:125). Mezraların da büyüklüğü geçim sahasıyla ilgilidir. Araştırma sahasındaki mezraları yerleşme büyüklüğü bakımından incelendiğinde birkaç evden, 20-30 haneye kadar değişmektedir.

Mezralar iktisadi özelliklerine göre Doğu Anadolu'da hayvancılık ve ziraat faaliyetleri Karadeniz'de yaylacılık ve rekreasyon faaliyetlerinin olduğu; yerleşme tarzına göre mevsimlik, semi sedanter ve sedanter olan; yerleşme dokusuna göre genel olarak, sadece hayvancilık yapılanlar gevşek dokulu sadece ziraat yapılanlar ise toplu dokulu bir karakter sergilemektedir.

Havzadaki mezralar ülke geneliyle ile karşılaştırıldığında yerleşme dokuları toplu karakterde, yerleşme tarzı bakımından formları itibariyle küme şeklindedirler. Bu kümeler bazı mezralarda tek parça halindeyken bazılarında birkaç parça halinde olabilmektedir. Mezraların birkaç parçada oluşmasında temel etken bazı ailelerin arazilerine yakın yerde evlerini yapması ve daha sonra bunlara yenilerinin eklenmesi etkili olmaktadır. Mezralar Karga Dağı ile Bulutlu, Pirhasan ve Heybeli Dağları'nda, drenaj ağının izin verdiği, kısmen daha az eğimli yamaçlarda kurulmuşlardır. Mezralar havzanın kuzeybatı ve doğu kesimlerinde (Yalındamlar düzü çevresi ile Topalkem havzası ve çevresinde) azalma gösterirken, güney ve güneybatı ile kuzeyde artış göstermektedir. Havza genelinde toplam 61 mezra yer almaktadır (Tablo 3).

Büyükçay havzasındaki mezralar, bulundukları konumları itibariyle daha çok yamaçlarda yer almaktadır. Buna bağlı olarak ulaşımın zor, gelişme ve büyümenin yavaş olduğu yerleşmelerdir. Araştırma sahasındaki bazı mezralar bağlı bulundukları köyden büyük olabilmektedir. Örneğin Yaylanlı köyünde 10 hane mevcutken, bağlı mezrası olan Kerim mezrasında 19 hane mevcuttur. Yine Topaluşağı köyünde 20 hane mevcutken, bağlısı Omikan mezrasında 45 hane mevcuttur. 
Mezralarda daha çok kayısı yetiştiriciliği yapılmaktadır. Ancak Sarıtaş, Karagedik, Meydancık köylerinde olduğu gibi klimatik veya topografik koşulların kayısı yetiştiriciliği için uygun olmadığı yerlerde, tahıl tarımı yapılmaktadır. Mezralar bağlı oldukları köyler gibi kış mevsiminde büyük ölçüde boşalmaktadır. Hayvancılık açısından mezralarda genel itibariyle ailelerin kendi ihtiyaçlarını karşılayabilecek kadar hayvan beslenmekte yani her meskende bir veya iki büyükbaş hayvan beslenmektedir. Ancak besicilik yaparak geçimini sağlayan aileler de mevcuttur (Aladikme-Silolar Mezrasi).

\section{MAHALLELER}

Köy ile mahallelerin sınırları belirgin değildir. Genelde sedanter bir karakter göstermesine rağmen bulunduğu bölgeye göre semi-sedanter bir yerleşme tarzına sahip olabilir. Köyler gibi yerleşme süresine göre daimi olan mahalleler yerleşme dokusu itibariyle bulunduğu coğrafi şartlara göre farkl1l1k gösterebilirler.

Tanoğlu mahalle-köy ayrımındaki kriteri, 2-25 haneyi mahalle, 25 haneden büyük olursa köy olarak belirtmiş(Tanoğlu, 1966:26); Tunçdilek ise "birden fazla iskân ünitesinin bir araya gelmesi ile oluşmuş yerleşmelerdir'” şeklinde tanımlamıştır.

Özçağlar, kırsal alanlardaki mahalleleri, bir köy idari alanı içinde aynı muhtarlığa bağlı olup, sürekli olarak ikamet edilen köy yerleşmeleridir şeklinde tanımlamak gerektiğini söylemiştir. Kır yerleşmelerini bir köy idari alanına bağlı kalmadan veya idari fonksiyon gözetmeden ele alındığında, mahalle yerleşmeleri ile köy yerleşmeleri arasına fazlaca farklılığın olmadığı görülür demiştir (Özçağlar,2009:83-84).

Kır yerleşmesi içinde hayli bir geniş yeri olan "mahalle" köy altı iskân şekillerinin en karakteristiği olmak gibi bir özelliğe sahip bulunur. Mahalle kır sayısı içindeki yeri ile iskânın bütün ağırlığını üzerinde taşır. Mahallenin büyük çoğunluğu birden fazla iskân gruplarını birleşmesinden meydana gelmiş yapay mahallelerde olabilir. Bütün bunlara rağmen mahalle, bir taraftan köy halk1 yerleşme şekillerini toplayıcı bir karaktere sahip bulunurken diğer taraftan birçok yerde köy ünitesinin temelini yerine getirir (Güngördü:56-57).

Kır iskanının adeta kaidesini teşkil eden mahalle sistemi, sahip olduğu hususiyetleri ile Türkiye'nin hemen her tarafina sokulmuş, bulunduğu yerde gelişmiş ve kelimenin tam manasıyla iskanı organize etmiş bir sistem olarak müşahade edilir. Hatta diğer iskan şekillerinden bazıları hayret edilecek kadar mahalleye benzedikleri görülür. Böylece daha başka isimlerle anılan o şekillerin fonksiyon bakımından mahalleden başka bir şey olmadıkları ortaya çıkar (Tunçdilek, 1967:107).

Araştırma sahasındaki mahalleler, Yalındamlar düzünde ve Topalkem havzasında yoğunlaşmaktadır ve toplamda 35 mahalle bulunmaktadır (Tablo 3). Bu iki kesimin mahallelerini karşılaştırdığımızda; Yalındamlar düzündeki mahalleler dokuları itibariyle toplu olsalar da mesken öbekleri arasındaki mesafenin daha fazla olduğu ve bunun sonucunda formları itibariyle şekilsiz olduğu gözlenmektedir. Topalkem havzasındaki mahalleler ise toplu dokuda meskenler ve mesken öbekleri arasındaki mesafenin daha az olduğu, form itibariyle küme şeklinde oldukları gözlenmektedir.

Havzadaki bazı mahalleler tıpkı mezralarda olduğu gibi bağlı bulundukları köyden büyük olabilmektedir. Bu durum havzadaki bütün yerleşmelerin aslında birer mezra veya mahalle yapısına sahip olmalarına rağmen bazılarının yalnızca köy idari merkezi konumuna sahip olmaları yönüyle diğerlerinden kısmen ayrıldığını göstermektedir.

Mahallelerin konumları, büyüme hızları üzerinde doğrudan etkili olmaktadır. Yalındamlar düzündeki mahallelerdeki hane sayıları, D-300 karayoluna ve Elazığ'a yakın olmasının sonucu olarak, Topalkem havzasındaki mahallelere göre daha hızlı artan bir yapıdadır. Bu nedenle bu kesimde yeni mahalleler ortaya çıkmaktadır. Ayrıca Yalındamlar düzünde ekonomik faaliyet çeşitliliği, Topalkem havzasına göre daha fazladır. Yalındamlar düzünde, kayısı yetiştiriciliğinden ziyade sulu tarım ve kuru tarım yapılmakta bunun yanında kümes hayvancılı̆̆ 1 , büyükbaş hayvancılık 


\section{F.Ü. Sosyal Bilimler Dergisi 2016-26/1}

ve arıcılık yapılmaktadır. Ayrıca şehre yakınlığının etkisiyle günübirlik şehirde çalışan insan sayısı da Topalkem havzasındaki mahallelere nazaran daha fazladır.

\section{YERLESMELERINN ŞEKLI}

Yerleşmelerin dış görünümleri şekil olarak belirtilmektedir. Sözlüklerde "ş̧ekil” sözcügü bir nesnenin dış çizgileri bakımından niteliği, dıştan görünüşü, biçimi olarak tanımlamaktadır. Bu durum da bir yerleşmenin yukarıdan kuş bakışı görünüşü, konutların arazi üzerindeki dağılım düzeni yerleşmenin şeklini ortaya çıkarmaktadır. Relief, su, iklim ve doğal bitki örtüsü koşuları; araziden faydalanma ve ulaşım durumu, yerleşmede yaşayan insanların birbirleriyle olan münasebetleri ile uygulanan yerleşim planları, yerleşmelerin şekil özellikleri üzerinde etkili olmaktadır (Özçağlar, 2009:79- 80)

Kır yerleşmeleri şekil yönünden öncelikle, çizgisel (rows) ve küme (agglomerations) oluşturan plânlar şeklinde ikiye ayrılabilir. Her iki tipin de düzenli (regular) ve düzensiz (irregular) şekilleri olabilir. Küme oluşturan planlar, düzenli ve düzensiz alt tiplerde olmak üzere 1zgara şekilli (grid) ve 1şınsal (radyal) planlar diye ayrılabilir (Özçağlar, 2009:79- 80).

Araştırma sahasındaki köylerin şekli bakımından sınıflandırdığımızda ağırlıklı olarak küme köylerin varlığı dikkati çekmektedir. Yerleşmenin şeklinin ortaya çıkmasında en önemli etkenin jeomorfolojik birimler olmasından hareketle sahadaki fiziki koşullar yerleşmelerin kümeler halinde ortaya çıkmasını sağlamıştır. Ancak kümeler halinde olan bu köylerdeki meskenler, çoğu yerde düzensiz bir karakter arz etmektedir.

Sahadaki diğer köylerin D-300 karayolunun ve araştırma sahasındaki vadilerin etkisiyle lineer (çizgisel) karakter sergiledikleri görülmektedir. Ortaçalı ve Küllük köyleri, meskenlerin düzensiz dağılmasına bağlı olarak herhangi bir şekle dahil edilmemiştir. Ancak her iki köyün de ilk kuruldukları yer itibariyle, küme şekli olarak belirtilebilir.

\section{YERLEŞMELERIN DOKUSU}

Yerleşme paterni (veya örüntü) ister köyde olduğu gibi toplu, isterse tek meskende ya da çiftlikteki gibi dağınık olsun, yerleşmelerin dokusal karakterini ortaya koyar. Patern genellikle ekonomik, tarihi ve kültürel etmenlerle ilişkili olarak belirmektedir. Yerleşme paterni veya dokusu toplu, dağınık ve gevşek tarzda ortaya çıkmaktadır ve zaman içinde değişime de açıktır. Tarımsal teknolojilerdeki ilerlemeler, nüfusun nicelik ve niteliğindeki değişiklikler, dokuda farklılaşmaya yol açmaktadır. Böylece, bazen bir toplanma, bazen bir dağılma ya da her ikisinin de olduğu örüntü tipleri meydana gelebilmektedir. Toplu veya çekirdek patern; genellikle ekstansif tarım ve açık tarla sistemlerinde; dağınık patern ise, bireysel tarım sistemi ve parçalı tarım arazileri olan yerlerde ortaya çıkmaktadır (Özgür, 2011:61-63).

Araştırma sahasının en belirgin ve önemli özelliklerinden biri de, yerleşmelerdeki saçılmadağılma-kümelenme süreci verilen tabloda kendini göstermektedir. Genel olarak arazideki köyler ve onlara bağlı birimlerin arazideki dokusu gevşek formdadır. Ancak burada belirtilmesi gereken bir diğer husus yerleşmelerin gevşek dokulu olması meskenlerin birbirinden uzakta olduğu anlamına gelmediğidir. Burada öbekler halinde beliren yerleşmelerde meskenler birbirine yakın ve toplu haldedir. Bu durum yalnızca Yalındamlar düzünde biraz azalmakta ve meskenler arasındaki mesafe artmaktadır (Harita 5, Şekil 1).

Havzada meskenler uydu görüntüleri üzerinden nokta atılarak konumları sayısallaştırılmış ve bu veri mekânsal istatistik araçlarından biri olan ortalama en yakın komşuluk (Average Nearest Neighbor) analizine tabi tutulmuştur. Analiz neticesinde meskenlerin küme şeklinde toplandığını meskenler arasında ortalama mesafenin 49,4 metre olduğu ve meskenlerin rastgele (düzensiz) bir şekilde dağılmış olması ihtimalinin \%1'dn daha az olduğu sonucuna ulaşılmıştır (Şekil 1). 
Büyükçay Havzasındaki (Elazı̆̆) Kırsal Yerleşmelerin...

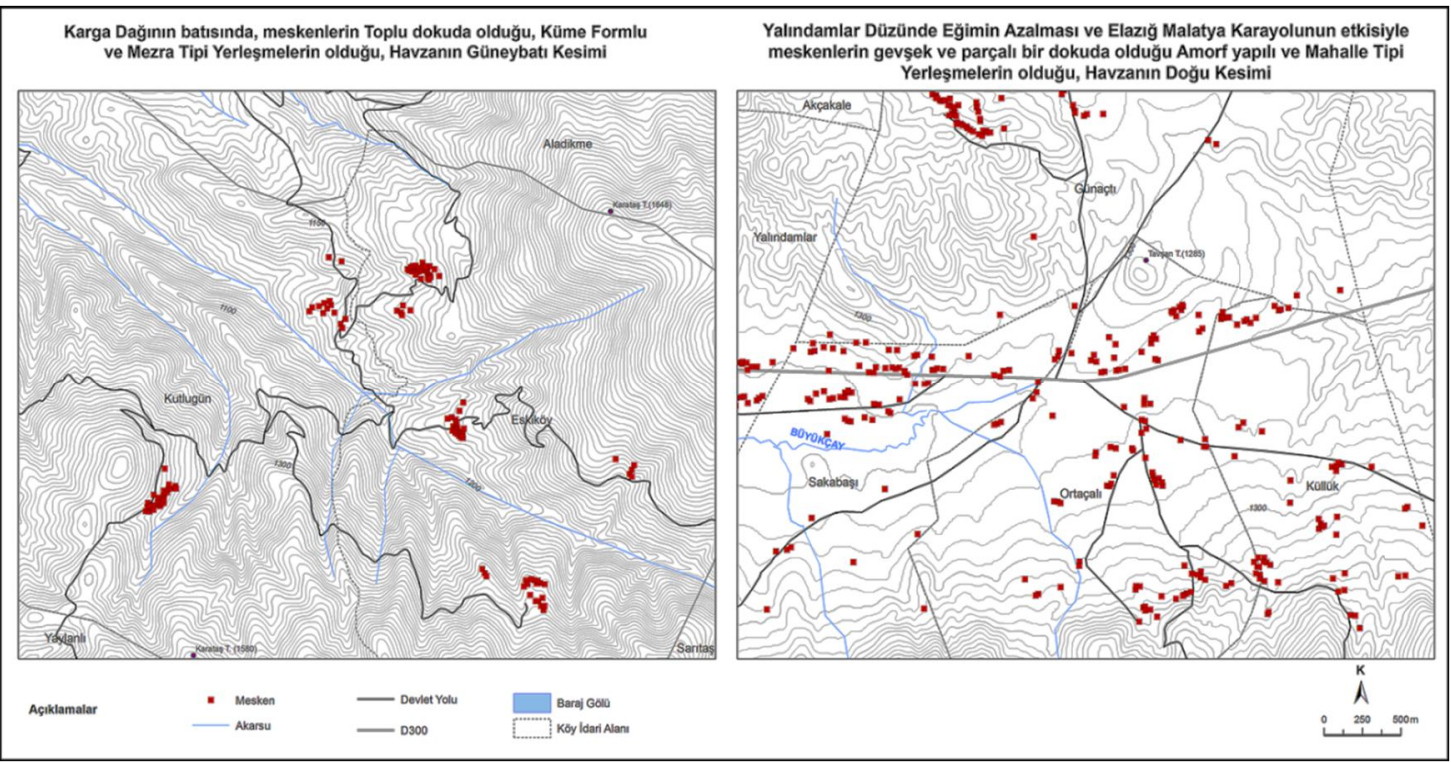

Harita 5: Araştırma Sahasının Doğu ve Batı kesimindeki Yerleşmelerin Dokusu ve Şekli (2014)

Bir yerde yerleşmelerin toplu veya dağınık olması içinde bulunduğu yakın çevre ile ilgilidir. Büyükçay havzasının doğusunda dağınık dokuya yakın bir yerleşme dokusu mevcut olduğu tespiti yapılırken, bunu Doğu Karadeniz bölümünün kırsal yerleşme dokusunda olduğu gibi değil (çünkü böyle bir durumda buraya toplu doku dememiz gerekecektir) Elazığ genelindeki kırsal yapı ile karş1laştırarak bu sonuca ulaşılmıştır. Araştırma sahasında eğimin fazla olduğu yerlerde yerleşmeler genelde toplu dokuya sahiptir. Bu durum, su kaynakları ile ilgili olduğu kadar akrabalık bağlarıyla da ilgilidir.

Havzadaki saçılma sürecine bağlı olarak yeni mezra ve mahalleler ortaya çıkmaktadır. İller İdaresi Genel Müdürlügü’nün verdiği bilgilerdeki kır-altı iskan birimi sayısı ile sahadaki kır-altı iskan birimi sayısı birbirini tutmamakta, daha fazla çıkmaktadır. Bu durumu örneklemek gerekirse; yeni oluşturulan mahallelere henüz isim verilmeyenler bile vardır. Bu durum sahadaki saçılmanın hızlı gerçekleştiğini göstermektedir.

Tablo 1: Yerleşmelerin Şekil ve Dokusal Sınıflandırılması

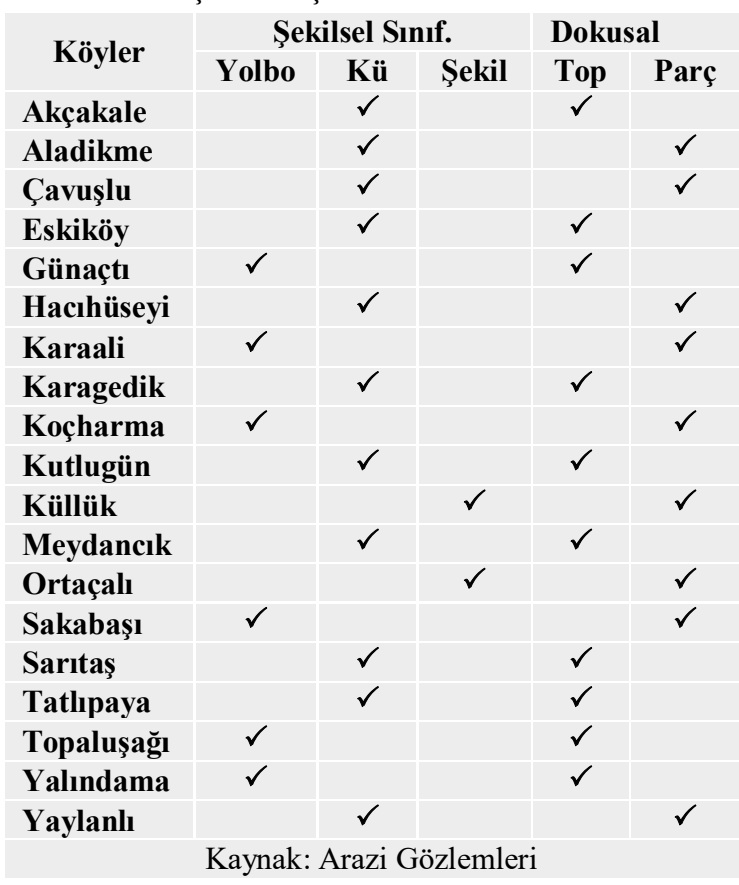

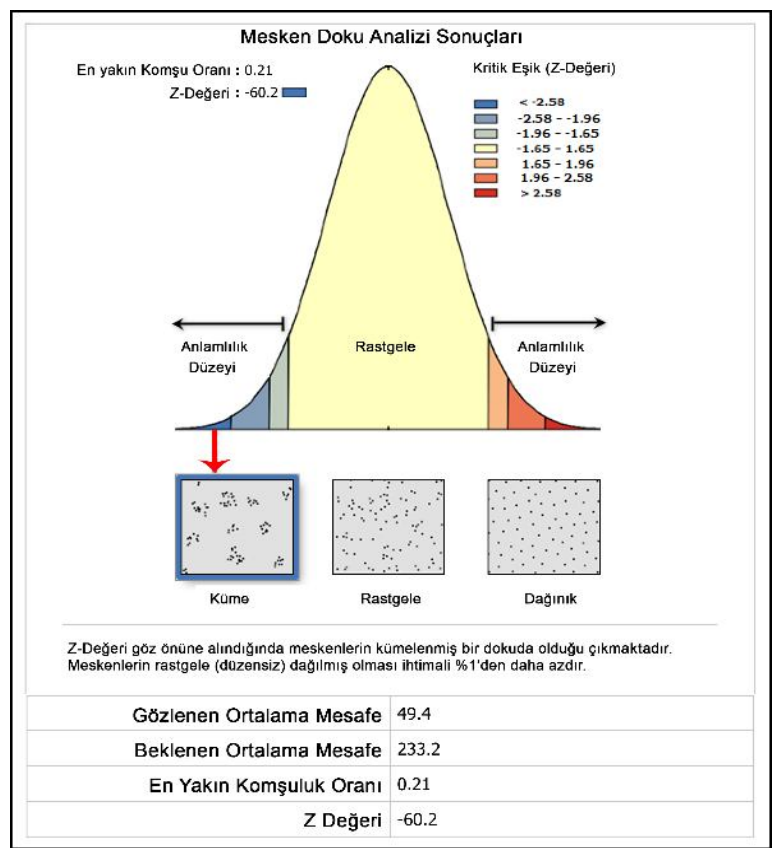

Şekil 1: Mesken Doku Analizi Sonuçları 
Sahada genel olarak görülen saçılma eğiliminin sebepleri şunlardır;

- Kayısı yetiştiriciliğine bağlı olarak gelir düzeyi arttıkça yerleşme dokusunda dağılma meydana gelmektedir. Ayrıca;

- Özel otomobil sahipliğinin artmas1,

- İnsanların tarım arazileriyle evleri arasındaki mesafeyi kaldırma isteği böylece arazisini daha iyi kontrol edebilme imkan1,

- Arazinin engebeli olmasının getirdiği parçalı arazi yapısı sonucu insanların buralarda evlerini yapmaları,

- Ulaşım imkanlarına bağlı olarak doğrudan ve hızlıca şehre ulaşma gerekliliği nedeniyle Elazı ̆̆-Malatya karayoluna yakın güzergahta oturma isteği,

- Teknik imkanları ekonomik gelişmeye bağlı olarak insanların kullanma imkanı arttıkça, her türlü ihtiyacın karşılanması köye uzak yerlerde de mesken yapımını ve ihtiyaçların karşılanmasını kolay hale gelmiştir.

\section{KÖYLERIN İDARİ YAPISI VE ADLARINA GÖRE SINIFLANDIRILMASI}

Türkiye' deki köy idari alanlarını bünyelerinde yer alan kırsal yerleşim ünitelerinin nicelik ve niteliklerine göre tek yerleşmeli mahalleli ve çok yerleşmeli olmak üzere üç grupta toplamak mümkündür (Özçağlar, 2005:6,9). Eğer köy devamlı bir yerleşmeden müteşekkil ise tek yerleşmeli, birden fazla mahallesi bulunuyorsa mahalleli, mahalle dışında köy-altı iskan birimleri mevcutsa çok yerleşmeli olarak sınıflandırılmaktadır.

Araştırma sahasında tek yerleşmeli köy tipi bulunmamaktadır. Sahanın engebeli yapısı tarım arazilerinin farklı yerlerde olmasına, dolayısıyla köy-altı yerleşim yeri sayısının artmasına neden olmuştur. Araştırma sahasında, 4 köy hariç, bütün köylerde mahalle dışında mezra da bulunmaktadır. Doğu Anadolu bölgesinde yoğun olarak görülen bu iskan birimi, havzada da topoğrafik koşullara bağlı olarak fazladır.

Araştırma sahasında Akçakale, Eskiköy ve Hacıhüseyinler köyleri hariç, bütün köylerin isimleri değiştirilmiştir. Önceki köy isimlerinin çoğu, köyü kuran aşiretin veya o köyde yaşayan nüfuzlu ailenin isimlerinden oluşmaktadır. Günümüzde köy altı iskan birimlerinde genellikle soy-sop adları etkili olmaktadır.

Yerleşme isimleri, birçok farklı değişkenle ilişkili olarak, uzun bir tarihsel süreçle ortaya çıkabileceğinden asli ismi üzerinden, toponimik analiz yapmak daha doğru olacaktır. Ancak yerleşmelerin ilk isimleri üzerinden böyle bir analiz yapmak için yeterli veri olmadığından böyle bir değerlendirme yapılamamaktadır. Bunun yanında çeşitli sebeplerle yeniden isimlendirilen köylerin de az bir kısmı, yöre insanının etkisiyle belirlendiğinden insanların mekana bakışı üzerinden yorum yapılabilir. Örneğin Çitik deresinin yamaçlarında bir geçit (Gedik) konumunda yer alan Karagedik köyü, Karga Dağının eteklerindeki bir su kaynağı üzerinde yer alan Sakabaşı (Saka:Su taşıyan kimse), Sarıtaş (Litoloji), Yaylanlı (Yayla: Dağlık, yüksek bölgelerde, kışın hayat şartları güç olduğu için boş bırakılan, yazın havası iyi ve serin olan, hayvan otlatma veya dinlenme yeri) köyleri bunlardan birkaçıdır.

Baskil ilçesine bağlı birçok köyün ismindeki "uşağı" eki yerleşim birimlerini kuran insanların akraba olmaları nedeniyle, köyde oturanların kimler olduğu belirtilmektedir. Topaluşağ köyü bu özelliğine bağlı olarak isimlendirilmiş bir köydür. Bazı köylerin eski isimlerinde de bu takıdan mevcuttur. Araştırma sahasındaki mezra isimlerinde de, bu özellikte birkaç mezra (Örneğin; Küllük köyüne bağlı Küllükuşağı mezrası, Sarıtaş köyüne bağlı Foduluşağı mezrası) mevcuttur.

\section{JEOMORFOLOJIK YÜZEYLER VE YERLEŞMELERIN KONUMLARI}

Köyleri sınıflandırmada kullanılan unsurlardan biri olan morfolojik ünitelere göre sınıflandırmada kullanılan ova, etek, vadi, sırt, yamaç vb. morfolojik şekiller geniş çapta tartışmaya açıktır (Tümertekin, 1973, s.77). Köylerin konumlarıyla ilgili olarak bu tartışmaları azaltmaya yönelik olarak, jeomorfoloji haritası ile arazi gözlemleri ve uydu görüntüleri üzerinden yapılan çalışmalar sonucu aşağıdaki tablo oluşturulmuştur. 
Büyükçay Havzasındaki (Elazığ) Kırsal Yerleşmelerin...

Tablo 2. Büyükçay Havzasındaki Yerleşmelerin Jeomorfolojik Birimlere Göre Dağılışı

\begin{tabular}{|l|c|c|}
\hline Jeomorfolojik Birimler & Yerleşme Sayısı & Oran (\%) \\
\hline Yamaç & 59 & 51 \\
\hline Vadi Tabanı ve Sekiler & 11 & 10 \\
\hline Alçak Platolar & 18 & 16 \\
\hline Yüksek Platolar & 9 & 8 \\
\hline Birikinti Koni ve Yelpazeleri & 18 & 16 \\
\hline Toplam & $\mathbf{1 1 5}$ & $\mathbf{1 0 0}$ \\
\hline
\end{tabular}

Kaynak: Köy Envanter Etütleri (1981), Siler (2009) Jeomorfoloji Haritası, Google Earth, Topografya Haritas1

Köyleri kuruluş yeri özellikleri bakımından incelediğinde; neredeyse bütün köylerin ilk kuruldukları yer değişmiştir. $\mathrm{Bu}$ durumla beraber bütün köylerde aynı zamanda, yayılma gerçekleşmiştir. Bu yayılmayı sahadaki mezra ve mahalle sayısının çokluğu göstermektedir.

Araştırma sahasında yer değiştiren yerleşmelere en belirgin örnek olarak Koçharmanı köyü (Şeruşağı) gösterilebilir. Bu köy, daha önce vadi içerisinde yer alan bir yerleşme iken, ulaşım güzergahına yakın olma ve arazileri üzerine insanların evlerini yapma istekleri nedeniyle yer değiştirmiştir ve günümüzde eski köy merkezinde kimse yaşamamaktadır. Ortaçalı ve Küllük köyleri ise, daha önce vadi içlerindeki uygun düzlüklerde yer alırken sel ve taşkın olayları, ekonomik faaliyet türündeki değişiklikler ve ulaşım sebeplerinden dolayı, vadinin aşağı kesimindeki birikinti konileri üzerine taşınmıştır. Akçakale köyü de, buna benzer bir şekilde doğuya doğru daha alçak bir yere taşınmıştır.

Büyükçay havzasındaki yerleşmelerin kuruldukları jeomorfolojik birimleri bakımından ele alındığında; yarıya yakınının (\% 51) vadiler ve akarsular tarafından parçalanmış az ve orta eğimli yamaçlarda toplanmış oldukları görülür. Havzanın en belirgin özelliği, Büyükçay ve kolları ile Fırat nehrinin oluşturduğu vadilerin fazlalığıdır. Bu durum yerleşmelerin lokasyonları üzerinde drenaj ağının belirleyici bir etkisi olmasını sağlamıştır. Topalkem havzası ile Günaçtı ve Akçakale köyü çevresi plato sahası olarak ele alınmış ve buradaki köy ve bağlı birimleri bu morfolojik ünite içerisinde değerlendirilmiştir (\%24). Birikinti koni ve yelpazelerinde yer alan yerleşmeler, Yalındamlar düzü ve çevresinde toplanmıştır (\%16). Vadi tabanı ve sekiler üzerinde yer alan yerleşmeler ise Büyükçay ve oluşturduğu sekiler üzerinde yer almaktadır (\%10), (Tablo 2 ve 3).

Havzada yerleşme üst sınırı 1722 metredir. Bu sınır, Elazığ il genelinde 1880 m'dir. En yüksekte yer alan yerleşme Sarıtaş köyüne bağlı Sekman mezrasıdır (1722 m.). Havzada en düşük rakıma sahip yerleşme Topaluşağı köyüne bağlı Geli mezrasıdır (699 m.). Yerleşmelerin ortalama yükseltisi 1206 metredir (Tablo 3). 


\section{F.Ü. Sosyal Bilimler Dergisi 2016-26/1}

Tablo 3. Havzadaki Kırsal Yerleşmelerin Eğim ve Yükselti Değerleri ile Morfolojik Konumları

\begin{tabular}{|c|c|c|c|c|c|}
\hline & Adı & Yer. Tipi & Ĕ̈imº ${ }^{0}$ & Mor.Kon. & Yükseltisi \\
\hline & Akçakale & Köy & 7 & Yüksek Plato & 1464 \\
\hline & Aşağı Akçakale & Mahalle & 12 & Yüksek Plato & 1411 \\
\hline & Yukarı Akçakale & Mahalle & 16 & Yamaç & 1542 \\
\hline 4 & Kutuşağı & Mezra & 8 & Yüksek Plato & 1441 \\
\hline 5 & Aladikme (Selvi Bozolar) & Köy & 20 & Yamaç & 1234 \\
\hline 6 & Aydoğan & Mezra & 5 & Yamaç & 1390 \\
\hline 7 & Bozolar & Mezra & 10 & Vadi Tab.ve Seki & 1032 \\
\hline 8 & Caddealtı & Mezra & 7 & Vadi Tab.ve Seki & 976 \\
\hline 9 & Cansızkayış & Mezra & 21 & Alçak Plato & 897 \\
\hline 10 & Çuğraș & Mezra & 23 & Alçak Plato & 855 \\
\hline 11 & Döşeli & Mezra & 2 & Alçak Plato & 920 \\
\hline 12 & Hacıömer & Mezra & 17 & Vadi Tab.ve Seki & 787 \\
\hline 13 & ibifar & Mezra & 10 & Alçak Plato & 849 \\
\hline 14 & Konacık & Mezra & 10 & Vadi Tab.ve Seki & 797 \\
\hline 15 & Selvi & Mezra & 10 & Yamaç & 1072 \\
\hline 16 & Silolar & Mezra & 16 & Vadi Tab.ve Seki & 844 \\
\hline 17 & Tekağaç & Mezra & 0 & Alçak Plato & 840 \\
\hline 18 & Üsük & Mezra & 0 & Alçak Plato & 890 \\
\hline 19 & Ünsaldı & Mezra & 14 & Vadi Tab.ve Seki & 711 \\
\hline 20 & Çavuşlu (Verdiham) & Köy & 12 & Yamaç & 1058 \\
\hline 21 & Aşağı Mahalle & Mahalle & 9 & Yamaç & 1074 \\
\hline 22 & Batı Galuşağı & Mahalle & 9 & Alçak Plato & 1018 \\
\hline 23 & Çapkurlar & Mahalle & 13 & Alçak Plato & 982 \\
\hline 24 & Doğu Galuşağı & Mahalle & 15 & Yamaç & 1167 \\
\hline 25 & ilanlar & Mahalle & 7 & Yamaç & 1069 \\
\hline 26 & Verd & Mahalle & 0 & Yamaç & 1130 \\
\hline 27 & Yeni Mahalle & Mahalle & 7 & Alçak Plato & 1035 \\
\hline 28 & Eskiköy & Köy & 15 & Yamaç & 1237 \\
\hline 29 & Akbayır & Mezra & 24 & Yamaç & 1398 \\
\hline 30 & Kanatlı & Mezra & 24 & Yamaç & 1455 \\
\hline 31 & Yapraklı & Mezra & 14 & Yamaç & 1212 \\
\hline 32 & Günaçtı (Torsçolak) & Köy & 2 & Yüksek Plato & 1340 \\
\hline 33 & Çolakuşağı & Mahalle & 6 & Yüksek Plato & 1328 \\
\hline 34 & Torsuşağı & Mahalle & 13 & Yüksek Plato & 1399 \\
\hline 35 & Yolüstü & Mahalle & 5 & Bir.Koni ve Yel. & 1267 \\
\hline 36 & Hacıhüseyinler & Köy & 19 & Yamaç & 1463 \\
\hline 37 & Erler & Mezra & 1 & Yamaç & 1470 \\
\hline 38 & Hacımustafa & Mezra & 16 & Yamaç & 1292 \\
\hline 39 & Keçiler & Mezra & 14 & Yamaç & 1392 \\
\hline 40 & Poğuzlu & Mezra & 15 & Yamaç & 1464 \\
\hline 41 & Yapraklı & Mezra & 24 & Yamaç & 1142 \\
\hline 42 & Yazarlar & Mezra & 15 & Yamaç & 1464 \\
\hline 43 & Karaali (Çaykaraali) & Köy & 9 & Yamaç & 1030 \\
\hline 44 & Çayırcık & Mahalle & 15 & Yamaç & 1089 \\
\hline 45 & Dükuşağ| & Mahalle & 5 & Alçak Plato & 965 \\
\hline 46 & Yoncalı & Mahalle & 2 & Alçak Plato & 1000 \\
\hline 47 & Dutluköy & Mahalle & 8 & Alçak Plato & 910 \\
\hline 48 & Harmanlı & Mezra & 19 & Yüksek Plato & 1178 \\
\hline 49 & Çakıllı & Mezra & 0 & Vadi Tab.ve Seki & 880 \\
\hline 50 & Şimșekler & Mezra & 16 & Vadi Tab.ve Seki & 1049 \\
\hline 51 & Karagedik (Yukarıhamuşağı) & Köy & 0 & Yamaç & 1540 \\
\hline 52 & Geli & Mezra & 20 & Yamaç & 1431 \\
\hline 53 & Kasuşağ| & Mezra & 8 & Yamaç & 1670 \\
\hline 54 & Alihacı & Mezra & 19 & Yamaç & 1553 \\
\hline 55 & Koçharmanı (Hasabur) & Köy & 13 & Vadi Tab.ve Seki & 1179 \\
\hline 56 & Doluca & Mahalle & 25 & Yamaç & 1198 \\
\hline 57 & Vali & Mahalle & 15 & Yamaç & 1208 \\
\hline 58 & Taşlıca & Mahalle & 18 & Vadi Tab.ve Seki & 1146 \\
\hline 59 & Baştaşlar & Mezra & 8 & Yamaç & 1129 \\
\hline 60 & Harikalanan & Mezra & 24 & Yamaç & 1112 \\
\hline 61 & Yukarı Koçharmanı & Mezra & 23 & Yamaç & 1390 \\
\hline
\end{tabular}

\begin{tabular}{|c|c|c|c|c|c|}
\hline & Adı & Yer. Tipi & Eğim $^{\circ}$ & Mor.Kon. & Yükseltisi \\
\hline & Kutlugün (Șeyhali) & Köy & 20 & Yamaç & 1313 \\
\hline 63 & Küllükuşağı & Mezra & 18 & Yamaç & 1081 \\
\hline 64 & Torsoları(Dayılar) & Mezra & 11 & Yamaç & 1108 \\
\hline 65 & Küllük (Gülik) & Köy & 0 & Bir.Koni ve Yel. & 1330 \\
\hline 66 & Halilağa & Mezra & 20 & Yamaç. & 1470 \\
\hline 67 & Yukarı Çolaklar & Mahalle & 6 & Bir.Koni ve Yel. & 1317 \\
\hline 68 & Meydancık (Bezkan) & Köy & 12 & Yamaç & 1551 \\
\hline 69 & Loğlar & Mezra & 18 & Yamaç & 1472 \\
\hline 70 & Ortaçalı (Sefernik) & Köy & 12 & Bir.Koni ve Yel. & 1352 \\
\hline 71 & Aslantaş & Mahalle & 2 & Bir.Koni ve Yel. & 1276 \\
\hline 72 & Kuyulu & Mahalle & 6 & Bir.Koni ve Yel. & 1326 \\
\hline 73 & Meduşağı & Mahalle & 9 & Bir.Koni ve Yel. & 1317 \\
\hline 74 & Oğuzlar & Mahalle & 1 & Bir.Koni ve Yel. & 1269 \\
\hline 75 & Davutlar & Mahalle & 2 & Bir.Koni ve Yel. & 1277 \\
\hline 76 & Sakabaşı (Pincirik) & Köy & 13 & Yamaç & 1565 \\
\hline 77 & Alikoç & Mezra & 15 & Yamaç & 1506 \\
\hline 78 & Şeyhoğulları & Mezra & 10 & Bir.Koni ve Yel. & 1337 \\
\hline 79 & Hacımahmut & Mezra & 11 & Yamaç & 1413 \\
\hline 80 & Kuyulu & Mezra & 17 & Bir.Koni ve Yel. & 1362 \\
\hline 81 & Cami & Mahalle & 12 & Bir.Koni ve Yel. & 1370 \\
\hline 82 & ilyas & Mahalle & 5 & Bir.Koni ve Yel. & 1301 \\
\hline 83 & Kayacık & Mahalle & 2 & Bir.Koni ve Yel. & 1256 \\
\hline 84 & Yeni Mahalle & Mahalle & 4 & Bir.Koni ve Yel. & 1252 \\
\hline 85 & Sarıtaş (Şavaluşağı) & Köy & 23 & Yamaç & 1630 \\
\hline 86 & Bozarmut & Mezra & 5 & Yamaç & 1620 \\
\hline 87 & Foduluşağ| & Mezra & 13 & Yamaç & 1468 \\
\hline 88 & Gulu & Mezra & 25 & Yamaç & 1483 \\
\hline 89 & Kalecik & Mezra & 18 & Yamaç & 1643 \\
\hline 90 & Palah & Mezra & 18 & Yamaç & 1532 \\
\hline 91 & Sekman & Mezra & 25 & Yamaç & 1722 \\
\hline 92 & Tatlıpayam (Sersük) & Köy & 16 & Yamaç & 1127 \\
\hline 93 & Dalık & Mahalle & 15 & Yamaç & 1091 \\
\hline 94 & Hasanan & Mahalle & 15 & Yamaç & 1120 \\
\hline 95 & Kiziruşağı & Mezra & 2 & Yamaç & 1160 \\
\hline 96 & Sincan & Mezra & 18 & Yamaç & 1213 \\
\hline 97 & Topaluşağı (Topalkem) & Köy & 1 & Alçak Plato & 930 \\
\hline 98 & Adacık & Mezra & 12 & Alçak Plato & 969 \\
\hline 99 & Geli & Mezra & 4 & Vadi Tab.ve Seki & 699 \\
\hline 100 & Sapanlı & Mezra & 12 & Alçak Plato & 987 \\
\hline 101 & Kemuşağ| & Mezra & 17 & Alçak Plato & 933 \\
\hline 102 & Omikan & Mezra & 20 & Alçak Plato & 937 \\
\hline 103 & Himik & Mahalle & 8 & Alçak Plato & 997 \\
\hline 104 & Yalındamlar (Güdeyik) & Köy & 2 & Bir.Koni ve Yel. & 1247 \\
\hline 105 & Karaca & Mahalle & 21 & Yüksek Plato & 1315 \\
\hline 106 & PInarlı & Mahalle & 7 & Bir.Koni ve Yel. & 1222 \\
\hline 107 & Yirikler & Mahalle & 2 & Bir.Koni ve Yel. & 1190 \\
\hline 108 & Yaylanlı (Kocikuşağı) & Köy & 15 & Yamaç & 1066 \\
\hline 109 & Kerim & Mezra & 16 & Yamaç & 969 \\
\hline 110 & Kuran & Mezra & 26 & Yamaç & 746 \\
\hline 111 & Çamaltı & Mezra & 20 & Yamaç & 837 \\
\hline 112 & Firat & Mezra & 13 & Yamaç & 927 \\
\hline 113 & Kurugöl & Mezra & 38 & Yüksek Plato & 1148 \\
\hline 114 & Mehmediye & Mezra & 35 & Yamaç & 1121 \\
\hline 115 & Mişmişler & Mezra & 16 & Yamaç & 1363 \\
\hline
\end{tabular}

Havzada 0-5 derece (\%0-9) arasında 25 yerleșme, 6-10 derece (\%10-18) 22 yerleșme, 11-15 derece (\%19-26) 28 yerleşme, 15-20 derece (\%27-37) 25 yerleşme, 21 derece ve üzeri $(\% 38+) 15$ yerleşme mevcuttur. Yalındamlar düzünden batıya doğru, Karga dağında ve Kömürhan boğazında eğim derecesi yüksek alanlarda, yerleşmeler artmaktadır (Tablo 3).

\section{TOPOGRAFIK KARAKTERIN ARAZİ KULLANIMINA ETKISİ}

Havzadaki topografik yapının arazi kullanımı üzerindeki etkilerini şu şekilde sıralayabiliriz;

- Tarım alanlarının konumu ve büyüklüğü 
- Parsel büyüklügü ve formu

- Tercih edilen ürün türü

- Hayvancilık faaliyetleri.

İki önemli dağlık kütle tarafından sınırlandırılan havzada tarım alanlarının konumu üzerinde tıpkı yerleşim yerlerinin seçiminde olduğu gibi drenaj ă̆ı etkili olmuştur. Drenaj ağına bağlı uygun eğimli yerlerde tarım alanları bulunmaktadır. Eğim değerine bağlı olarak teraslama yapılarak kullanılan tarım alanlarına havzanın birçok yerinde rastlamak mümkündür.

Tarım alanlarının büyüklüğü ve bütünlüğü üzerinde de aynı koşulların etkisi söz konusudur. Karga Dağı ve Bulutlu Dağı üzerindeki köylerde birkaç küme halinde tarım alanları mevcutken, Yalındamlar düzü ve Topalkem havzasında eğim değerlerinin azalmasına bağlı olarak tek parça halinde bütünlüğ̈̈ olan ve alansal olarak daha büyük tarım alanları ve parseller mevcuttur.

Havzadaki VII. Sınıf araziler toplam alanın \% 83'ünü $\left(226,3 \mathrm{~km}^{2}\right)$ oluşturmaktadır. Havzadaki temel topografik ünitelerden olan Bulutlu Dağı, Pirhasan Dağı, Heybeli Dağı ve Karga Dağının çok büyük bir kısmı bu sınıfa dahildir. Bu araziler çok fazla özen gösterilmek kaydıyla çayır veya orman olarak kullanılabilecek araziler olarak belirtilmektedir. Ancak bu araziler, Eskiköy, Kutlugün, Topaluşağı, Aladikme ve Koçharmanı köyleri başta olmak üzere diğer köylerde de, arazinin bir bölümü kayısı yetiştiriciliği yapılarak değerlendirilmekte ve III.sınıf arazi gibi kullanılmaktadır. Ayrıca Hacıhüseyinler, Yaylanlı ve Sarıtaş köyleri başta olmak üzere diğer köylerde de tahıl tarımı yapılan VII.sinıf araziler mevcuttur. Bu durum havzadaki kabiliyet sinıflarının insan kontrolünde nasıl değişikliğe uğrayabileceğine güzel bir örnektir.

Parsel büyüklükleri ve formları havzada eğimli yüzeylerde farklılaşmaktadır. Örneğin Eskiköyde tarla sınırları genelde düz hat şeklinde uzanırken (şerit parsel), eğimli yüzeylerde tarla sınırları kavislenmektedir. Yine bu köyde tarım alanları parçalı arazi yapısının etkisiyle tarım alanları da 5 ayrı parçadan oluşmaktadır. Yani tarım alanlarında bir bütünlük bulunmamaktadır. Eğim değerlerinin azaldığı havzanın doğusundaki Günaçtı köyünde ise, parseller biraz daha büyük ve toplu bir yapıdadır. Diagonal yapı Eskiköy'e göre daha belirgin olarak Günaçtı köyünde hakim durumdadır.

Drenaj ağına bağlı ortaya çıkmış ve kısmen daha az eğimli yüzeyler, köylerin kurulduğu yerler kadar tarımsal arazilerin de ortaya çıkmasını sağlamıştır. Bu az eğimli yüzeylerde parsellerin, vadilere uygun hatlar izlemesine neden olmuştur. Eğim değerinin arttığı yerlerde teraslama yapılarak kullanılan tarım alanlarına, havzanın birçok yerinde rastlamak mümkündür.

Büyükçay havzasında köylerin temel ekonomik fonksiyonu bakımından büyük farklılıklar yoktur. Havzadaki köylerin büyük bölümü bahçe tarımı ile geçimini sağlamaktadır. Havzada bir ayrım yapılacak olursa, doğuda havzanın başlangıcından Karaali boğazına kadarki kesimde tarla tarımı, bağ ve bahçe tarımı ile sulu tarım alanları karma halde yapılırken boğazın batısına doğru daha tek tip halde bahçe tarımı önem kazanmaktadır. Karagedik köyü hariç köylerin tamamında hayvancılık yalnızca kendi ihtiyaçlarını karşılayacak kadar ya da çok az miktarda, ticari amaçla yapılmaktadır. Dolayısıyla geçim kaynağı olarak hayvancılık, Karagedik köyü hariç, bütün köylerde son sirada yer almaktadır.

Karagedik köyünde ilk sırada hayvancılığın olması, tarımsal aktiviteler için uygun arazinin yeterince olmaması ve çevresine göre daha serin hava koşulları göstermesinden kaynaklanmaktadır. $\mathrm{Bu}$ durumu göstermesi bakımından burada serin hava koşullarını seven ceviz meyvesinin fazla olması belirtilebilir.

Araştırma sahasında bahçe tarımındaki en önemli ürün kayısıdır. Kayısı yetiştiriciliğinin geçim kaynakları içerisinde genelde ilk sırada olması, kayısının havzada rantabl olarak üretilebilecek ve getirisi yüksek bir bitkisel ürün olması dolayısıyladır. Ayrıca buradaki engebeli arazi koşulları, bahçe tarımının geçim kaynağı olarak tarla tarımına göre daha ön plana çıkmasını sağlamıştır. 


\section{F.Ü. Sosyal Bilimler Dergisi 2016-26/1}

Arazi miktarları ile nüfus arasında doğrudan bir bağlantı yoktur. Arazi bakımından küçük bir köy olan Yalındamlar $(8.7$ km², 300 kişi) nüfusu itibariyle büyük; arazi bakımından oldukça büyük olan Akçakale köyü (19.4 km², 64 kiși) ise nüfusu itibariyle oldukça küçük bir köydür.

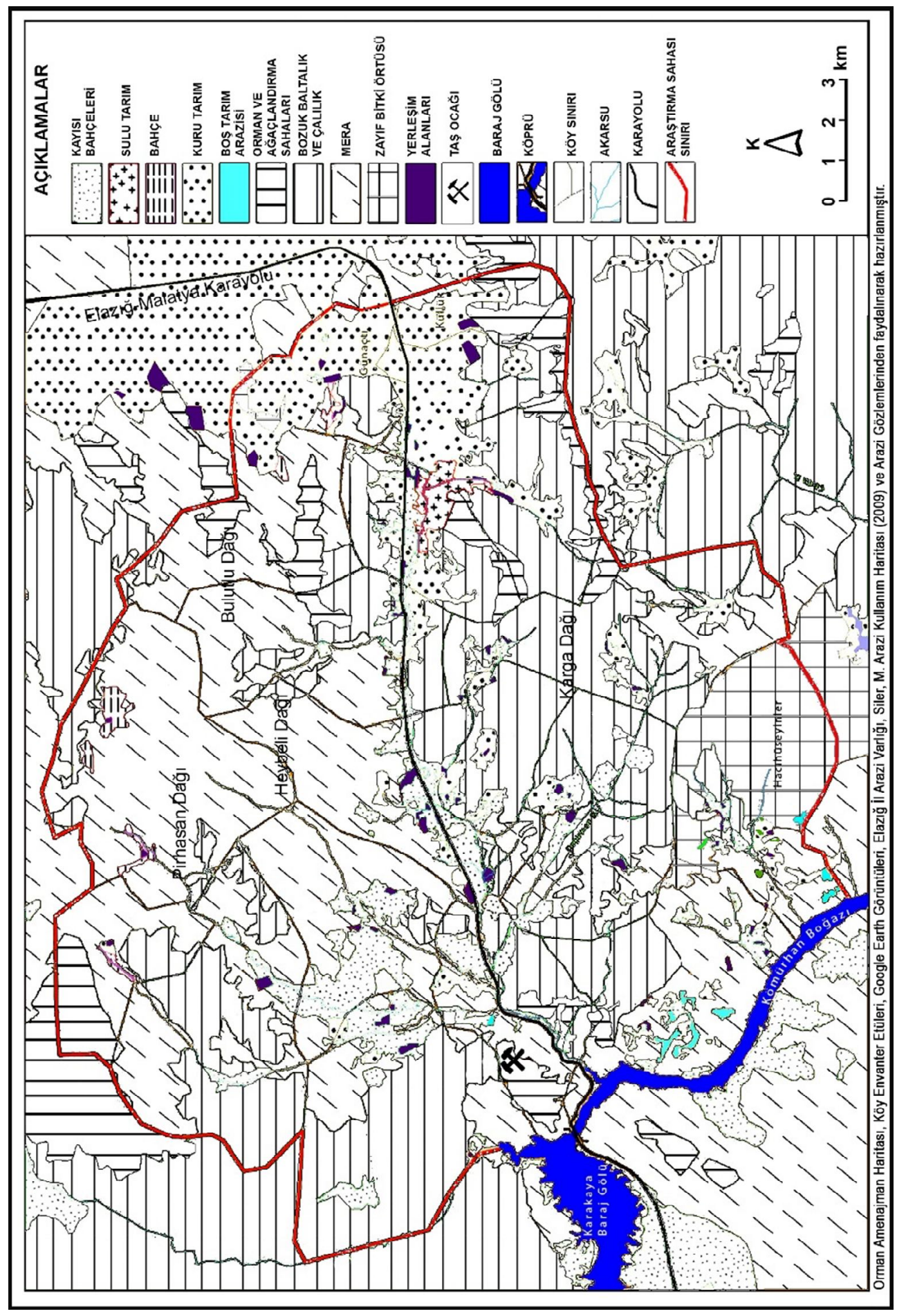

Harita 6. Büyükçay Havzasında Genel Arazi Kullanımı (2010)

Köylerle ilgili burada belirtilmesi gereken bir başka husus da köy sınırlarıdır. Bu çalışma başlangıcında elde edilen 1981 köy karnelerindeki köy sınırları ile tapu-kadastrodaki köy sınırları birbirleriyle uyuşmamaktadır. Bu durum sahamızda en belirgin olarak Aladikme-Çavuşlu köyleri arasında görülmektedir. Köy karnelerindeki haritalarda Büyükçay sınır olarak gösterilmesine 
rağmen, çayın karşısında Aladikme'ye ait birkaç mezra bulunmakta ve Çavuşlu'nun sınırları güneyden daralmaktadır. Bu durum Çavuşlu ve Aladikme'ye ait haritalarda verilen sayılarının da yanlış olmasına neden olmaktadır.

\section{SONUÇ}

Büyükçay havzası iki farklı coğrafi ünite (Malatya havzası ile Uluova) arasında eşik sahası olması nedeniyle geçiş alanı özelliği göstermektedir. Bu geçiş özelliği havzanın nüfus, yerleşme ve iktisadi özelliklerine yansımış ve belirleyici olmuştur.

Yerleşmelerin bariz özellikleri arasında, köylerin çok sayıda köy altı iskan birimine sahip olması gösterilebilir. Havzada köy merkezleri ile birlikte 110'den fazla yerleşme bulunmaktadır. Bunun en önemli sebebi topografik şartlar yüzünden havzada yerleşmeye ya da tarıma uygun sahaların birbirinden kopuk halde bulunmasıdır. Bu durum yerleşmelerin öbekler halinde ayrı ayrı yerlerde toplanmasina neden olmuştur.

Havzadaki yerleşmeler şekil özellikleri açısından daha çok yol boyu köyler ve küme köyler formuna sahip yerleşmelerdir. Dokusu bakımından dağınık yerleşmelerin olmadığı ancak parçalı ve toplu dokulu yerleşmelerin mevcut olduğunu da belirtebiliriz. Yerleşmelerin kuruluş yeri olarak daha çok vadiler ve yakın çevresini seçtiği görülmektedir. Araştırma sahasındaki yerleşmelerde yerleşme süresi sürekli olmasına rağmen yerleşme tarzı bakımından mevsimsel bir karakter dikkat çekmektedir.

Yükselti, eğim ve orografinin yanında hidrografik karakter de havzadaki yerleşme yapısının oluşmasında etkili olan öncelikli doğal faktörlerdir. Orografiye bağlı ortaya çıkan Elazı̆̆ Malatya karayolunun konumu ve şehre yakınlık, yerleşme yapısı üzerinde etkili olan beşeri faktörlerdir. Sonuç olarak araştırma sahası coğrafi ortam koşullarına bağlı olarak kendine has bir bütünlük gösteren, çevresine göre de farklılık arz eden bir saha özelliği taşımaktadır.

\section{KAYNAKÇA}

AKDEMİ, İ. O., (1996), Muratçık (Aşvan) Ovasının (Elazığ) Yerleşim Tarihi, F.Ü. Sos. Bil. Ens. Der. C:8, S:1, s:47-62, Elazı̆̆.

ALAGÖZ C.A., (1941), "Yayla Tabiri Hakkında Rapor", Birinci Coğrafya Kongresi Raporları, s.150157, Ankara.

BABUŞ, F., (2006), Osmanlı' dan Günümüze Etnik-Sosyal Politikalar Çerçevesinde Göç ve İskan Siyaseti Uygulamaları, Ozan Yayınc1lık, İstanbul.

CANPOLAT, F.A.,(2011), Büyükçay Havzasının (Elazığ) Beşeri ve Ekeonomik Coğrafyası, Fırat Üniv., Sosyal Bilimler Enst. Coğ. Ana Bilim Dalı (Basılmamış Yüksek Lisans Tezi), Elazığ.

ÇAKAR, E., (2012), Elazığ Baskil Yöresi Aşiretleri, Ankara.

DENKER, B. T., (1977), Yerleşme Coğrafyas1, İst. Üniv. Coğ. Enst. Yay. No:93 İstanbul.

DİE, Genel Nüfus Sayımları, Ankara.

DOĞANAY H., KOCA H., (1998), "Ulaşımın Yerleşmeye Etkilerine İki Tipik Örnek: Fevzipaşa ve Nurdağı Kasabaları” Türk Coğ. Der., S.33, s.1-24, İstanbul.

DOĞANAY, H., (1994), Türkiye Beşeri Coğrafyası, Gazi Büro Kitapevi, Ankara.

GÖZENÇ, S., GÜMÜŞ, E., ERTİN, G. (1994), Türkiye Coğrafyası, AÖF Yayınları No:594, Eskişehir.

GÜRSOY, C. (1974), “Türkiye'nin Tabii Yolları”, Türk Coğrafya Dergisi, S.26, s.24- 33, İstanbul.

GÜNGÖRDÜ E., (2006), Türkiye'nin Beşeri (Nüfus-Yerleşme ) ve Ekonomik Coğrafya 5. Baskı, Ankara.

HAYLİ, S. (1995), Erzincan Ovasının Beşeri ve İktisadi Coğrafyası, Fırat Üniv., Sosyal Bilimler Enst. Coğ. Ana Bilim Dalı (Basılmamış Doktora Tezi), Elazı̆̆.

HAYLİ, S., ALTINBÍLEK, M.S. (2001), "Erzincan Ovası ve Yakın Çevresindeki Köylerin Başlıca Coğrafi Özellikleri”, Atatürk Üni. Erzincan Eğitim Fakültesi Dergisi, C.3, S.1, sf.89-116, Erzincan. 
IŞIKLI, M., (2014), "Yükseklerde Arkeoloji Yapmak. Doğu Anadolu Arkeolojisinin Dünü-Bugünü”, Arkeolojiyle Geçen Bir Yaşam İçin Yazılar Veli Sevin'e Armağan, Ege Yayınları, İzmir.

ÖZÇAĞLAR A., (1996), "Türkiye'de İdari Coğrafi Bakımında Köy, Bucak, ilçe, İl, Belde Kavramları Üzerine Düşünceler”, A.Ü.D.T.C.F., Coğ. Arşt. Der. S.12, s.7-24, Ankara.

ÖZÇAĞLAR A., (2005), "Türkiye'de Mülki İdare Bölümlerinin İdari Coğrafya Analizi," Coğ. Bil. Der. S.3 s.1-25, Ankara.

ÖZÇAĞLAR A., (2009), İdari Coğrafya Ders Notları (Yayınlanmamış), DTCF, Ankara.

ÖZGÜR, E. M., (2010)-2, Yerleşme Coğrafyası, Ankara Üniversitesi Dil ve Tarih, Coğrafya Fakültesi Coğrafya Bölümü Ders Notları, Ankara.

SARIBEYOĞLU, M., (1951), Aşağı Murat Bölgesinin Beşeri Coğrafyası, A.Ü. DTCF Doğu Anadolu Araştırmaları İstasyonu. Yay. No: 1, Ankara. İstanbul.

SERGÜN, Ü., 1975, Beşeri Coğrafya Açısından Bir Araştırma: Uluova, İ.Ü. Coğr. Enst. Yay. No: 82,

SíLER, M.,(2009), "Büyük Çay Havzası'nın (Elazı̆̆ Batısı) Genel ve Uygulamalı Jeomorfolojisi”, Fırat Üniv., Sosyal Bilimler Enst. Coğ. Ana Bilim Dalı (Basılmamış Yüksek Lisans Tezi), Elazı̆̆g.

TANOĞLU A., (1969), Nüfus ve Yerleşme, İst. Ünv. Yay. 1183, İstanbul.

TUNÇDíLEK N., (1967), “Türkiye İskân Coğrafyası Kır İskânı” İst. Ünv. Coğ. Enst. Yay. S.49, s.144-145, İstanbul.

TUNÇDíLEK N., (1971), "Kır Yerleşmeleri: Köy-Altı Şekilleri” Türkiye Coğrafi ve Sosyal Araştırmalar, s.17-55, İstanbul.

TUNÇDíLEK N., (1978), “Türkiye'nin Kır Potansiyeli ve Sorunları” İst. Ünv. Coğ. Ens. Yay. No. 96, İstanbul.

ÜNAL, M. A., (1989), “XVI. yy’da Harput Sancağı”, AKDTYK, TTK Yay., XIV. Dizi, Ankara.

TÜİK, Adrese Dayalı Nüfus Kayıt Sistemi Sonuçları, Ankara.

YİĞíT, A., (1994), Sivrice-Maden Yöresinin Mevzi Coğrafyası (Basılmamış Doktora Tezi), Fırat Üniversitesi, Sosyal Bilimler Enstiüsü, Elazığ.

YİĞíT, A., HAYLİ, S. (1995), "Hazar Gölü ve Behrimaz Havzalarında Kır Yerleşmelerinin Coğrafi Özellikleri”, 1. Hazar Gölü ve Çevresi Sempozyumu Bildiriler, Sivrice Kaymakamlığı Yay.No: 2, sf:203-218, Sivrice-Elazığ. 